\title{
Current Standing and Future Prospects for the Technologies Proposed to Transform Toxicity Testing in the $21^{\text {st }}$ Century
}

\section{Erwin van Vliet}

Johns Hopkins University, Bloomberg School of Public Health, Center for Alternatives to Animal Testing (CAAT), Baltimore, USA

\author{
Summary \\ The National Academy of Sciences publication, Toxicity Testing in the $21^{\text {st }}$ Century: A Vision and a \\ Strategy, proposes a paradigm shift in toxicology from current animal-based testing towards the application \\ of emerging technologies, i.e., assays based on human cells or non-mammalian models, high throughput \\ testing, omics approaches, systems biology, and computational modeling. These technologies should \\ be used to identify how chemicals interact with cellular response networks and alter them to toxicity \\ pathways. According to the authors, such a new paradigm would provide a better scientific understanding \\ and more adequate data to predict the adverse effects of chemicals on human health. As expected from \\ a vision document, the report enthusiastically and optimistically describes a radical transformation of \\ toxicology from current practices to a new approach. Several toxicologists have commented on the report, \\ and although they generally confirm the importance of the vision, they pose critical questions regarding its \\ feasibility. Unlike the theoretical concepts, which are carefully described, many practical aspects of how \\ to establish the vision are less well defined. Today's technologies provide great opportunities, although \\ many challenges remain regarding their development, implementation, and validation to adequately assess \\ human health effects. To bring the envisioned toxicology closer to concrete implementation, it is important \\ to identify the current knowledge gaps in the vision and develop solutions. The goal of this review is to \\ evaluate the technologies proposed as to their maturation to transform toxicity testing in the $21^{\text {st }}$ century. \\ This paper will provide an overview of the current standing by defining advantages, limitations, and \\ developmental needs. In doing so, I do not intend to point out obstacles but, rather, to focus on current \\ opportunities to advance toxicity testing for human risk assessment.
}

Keywords: in vitro toxicology, stem cells, high throughput, imaging, omics, systems biology, testing strategies

\section{Introduction}

Despite the major scientific advances made in the field of molecular biology, biotechnology, and bioinformatics, the basic concepts of regulatory toxicology have hardly changed over the past decades. The publication of the National Academy of Sciences and National Research Council report: Toxicity Testing in the $21^{\text {st }}$ Century: A Vision and a Strategy (NRC, 2007), has led to a broad discussion regarding the need for a paradigm shift in the field of toxicology to implement the latest opportunities the life sciences have to offer. The report, henceforth referred to as "the vision," was commissioned by the U.S. Environmental Protection Agency (EPA) and proposes a transformation in toxicology from a system based on animal testing to one relying on cell-based assays, high throughput testing, omics approaches, and computational modeling. The committee that wrote the report expects these approaches to generate data that is more suit- able for the assessment of human toxicity than data obtained by current animal tests (Schmidt, 2009). Although the vision is generally supported by toxicologists, some have expressed concerns regarding its feasibility (Meek and Doull, 2009; Schwartz, 2010; Waddell, 2010; Phalen, 2010).

Currently, much of toxicology relies primarily on traditional whole-animal experiments, which are well accepted by the regulatory community. Although it is recognized that many animal models can be useful in predicting human health effects, they are not always the best choice (Olson et al., 2000; Bracken, 2009; Knight, 2007; Hartung, 2008). The main drawbacks of animal experiments include: they are time consuming - for example the 2-year rat bioassay for carcinogenicity (Bucher, 2002); they are expensive, with an estimated $\$ 3$ billion a year spent worldwide (Bottini and Hartung, 2009); and they do not always predict tox-

Received 06.10.10; received in revised form and accepted for publication 14.12.10 
ic effects in humans, since retrospective analysis suggests that about $20-30 \%$ of adverse drug reactions are not detected during preclinical safety testing (Stevens, 2006). To maximize safety levels, toxicological studies are designed according to a highly cautious approach in order to minimize the number of false negatives (not correctly identified hazards). This means that animals are often exposed to high maximum tolerable doses, which is very different from the real-life situation where humans are exposed to low doses of chemicals or environmental agents over longer periods of time. This design can lead to inaccurate predictions, the generation of false positives (Hoffmann and Hartung, 2005; Leist et al., 2008), and, consequently, the loss of valuable chemicals and lead substances for industry (Hartung, 2009b). Meanwhile, we still do not exactly know the risks of long-term exposure to low levels of environmental agents and industrial chemicals for human health (Schmidt, 2009).

Advances in the life sciences have provided a variety of new technologies to investigate the adverse effects of environmental agents in a more mechanistic, less expensive, and time saving manner. Some of the most promising include primary cell culture models, human stem cells, high throughput testing, imaging technologies, omics approaches, integrated test strategies, and systems biology. In the vision these technologies are proposed for the investigation of pathways of toxicity. Instead of the standardized "black box" animal test, which provides only limited mechanistic information, comprehensive screening studies are undertaken to reveal the interactions of chemicals with biochemical pathways that control cell function, communication, and adaptation to environmental changes. It is believed that chemicals can interact with these pathways, thereby altering their normal functions leading to toxicity and disease. The number of existing pathways is still a matter of debate. Most scientists believe that the number is finite, estimating hundreds to a thousand possible pathways; some others, however, believe that biological complexity can generate an infinite number of interlinked pathways (Schmidt, 2009). A promising hypothesis is that some toxicity pathways could be conserved across species. The eventual goal is to apply pathway-based risk assessment, where a relevant concentration of a compound perturbing a pathway of toxicity in a (preferably) human cell culture system is related to human blood or tissue concentration and thereafter modeled to a human dose that would lead to this. The prediction of a relevant human dose and its human risk assessment will be based on physiologically based pharmacokinetic (PBPK) modeling, which applies human pharmacokinetic parameters and data of dosimetry studies in human populations (Krewski et al., 2009).

Although the report received much attention, the need to introduce new concepts into toxicology is not a recent issue. Scientists have suggested the development and use of more humane and better, science-based alternative approaches in toxicology for many years (Goldberg, 1983; Zbinden, 1990a,b; Balls, 1998; Hartung, 2001; Coecke et al., 2007). However, it seems that support for the proposed paradigm shift in toxicology is currently growing, considering the generally supportive comments on the vision (Seidle and Stephens, 2009; Chapin and Stedman, 2009; Bus and Becker, 2009; MacDonald and Robertson, 2009; Hartung and Daston, 2009). Several factors have played a key role in this increasing support. The first is that the demand for toxicological information on chemicals now is largely exceeding the ability to produce relevant data based on the current regulatory animal tests. At present, there are about 80,000 chemicals on the market, and each year about 2,000 new chemicals are introduced for which there is limited or no adequate toxicological information (US EPA, 1998a,b; Bakand et al., 2005; Grandjean and Landrigan, 2006; Rand, 2010). The second reason is that our society is increasingly less willing to accept risks in consumer products or in the environment. The largest safety assessment of chemicals is now underway in Europe: The registration, evaluation, authorization, and restriction of chemicals (REACH) legislation (EC, 2006) aims to test 30,000 chemicals produced in quantities of more than one ton per year, for which no adequate information exists on their toxicological properties. Toxicologists and regulators are still debating the expected costs and animal numbers required for the REACH program. The latest estimates show much higher costs ( $€ 9.5$ billion) and vertebrate animal numbers ( 54 million) than initially expected, leading to concerns about the feasibility and ethics of such a large amount of in vivo toxicity testing (Rovida and Hartung, 2009). In order to reduce time, costs, and animal numbers, REACH foresees the use of in vitro and in silico methods. Nevertheless, the appropriate methods must be available and capable of providing the required information.

Although the paradigm shift seems to have taken off, toxicology will not move quickly from animal experiments to in vitro and in silico based testing strategies. Like other advances in science, this will be an ongoing process. Since the publication of the vision report in 2007, a large number of published reviews have addressed the practical and economical feasibility of the vision and its possible impact on human risk assessment (Andersen and Krewski, 2009; Krewski et al., 2009; Seidle and Stephens, 2009; Hartung, 2009a). The goal of this article is to review the current status of the technologies proposed in the vision and to identify knowledge gaps where more development is required. The opportunities primary cell models, human stem cells, high throughput testing, imaging, omics, and systems biology have to offer at this moment are presented and their limitations and developmental needs for the future are addressed. Finally, the challenges of how to integrate newly developed approaches into efficient testing strategies are discussed.

\section{Promising in vitro models for toxicity testing}

In the envisioned regulatory toxicology, in vitro models will provide the main biological systems for toxicity testing instead of currently used whole-animal models (Andersen and Krewski, 2009). The first critical question asked by regulatory toxicologists is, how closely do these in vitro models represent the in vivo situation and how accurately can they predict adverse effects on human health (Hartung and Daston, 2009)? Cell culture methodologies have improved substantially over the last decades, 
leading to a number of promising cell models that comprise relevant morphological and biochemical signaling processes. In general, in vitro toxicity testing has advanced from the study of cells in culture to the study of reconstructed tissue equivalents, which aim to reproduce the in vivo environment (Carere et al., 2002). Moreover, human cells are increasingly used to avoid species differences in toxicity predictions.

\subsection{Primary monolayer and three-dimensional cell cultures}

Today's most complex cell culture models are generally derived from primary cells freshly isolated from either animal or human tissues (Tab. 1). Primary cell cultures can be prepared from liver, brain, kidney, or skin tissue and were shown to maintain morphological and biochemical in vivo characteristics (Tiffany-Castiglioni et al., 1999; Guillouzo, 1998; Pfaller and Gstraunthaler, 1998). Primary cells are normally grown under monolayer conditions, but since this represents a simplified and artificial model of the in vivo situation, growing cells within a three-dimensional (3D) structure has become increasingly popular (Griffith and Swartz, 2006). The third dimension is obtained by growing cells in media suspensions, on artificial substrates (e.g. scaffolds), or in matrix-based conditions (e.g., agars and gels) (Lee et al., 2008). Several comparative studies between primary $3 \mathrm{D}$ and monolayer cultures have shown improvements in cell function and behavior, including improved cell-cell interactions, signal transduction, and gene expression (Mazzoleni et al., 2009; Pampaloni et al., 2009). Because 3D models reproduce and maintain organ-specific functions better, the interest in developing and applying these models for toxicity testing has increased during the last years (Stevens, 2009; Pampaloni et al., 2009). In addition, however, the third dimension also brings a number of new challenges to the field of cell culture. The multiple cell layers raise concerns regarding a sufficient supply of oxygen and nutrients to the core of the cell cultures. Moreover, toxic metabolites can accumulate, leading to central necrosis.
Therefore, cell models need to be well characterized and maintained under optimized and standardized culture conditions. Although 3D models are increasingly used, most commercial toxicity endpoints are still adjusted to monolayer cultures in multi-well plates. Thus, to fully exploit the third dimension in cell culture, more appropriate endpoints need to be developed, e.g., biochemical assays or imaging technologies. Primary cell models that closely reproduce the in vivo situation combined with sensitive multi-parametric endpoints, e.g., omics or high content imaging approaches, represent some of the most promising test systems for the identification of toxicity pathways.

\subsubsection{Primary cell models reproducing the liver}

The development of cell culture models reproducing the liver has received much attention. The liver is the main organ in which the biotransformation of chemicals and drugs involving phase I and II metabolizing enzymes takes place (Guillouzo, 1998). Toxic compounds can either be detoxified or an initially non-toxic parent compound can be transformed into toxic metabolites. Therefore, the presence of metabolic competence is often a critical concern in the field of in vitro toxicology (Coecke et al., 2006). To include metabolic competence, commercially available subcellular liver enzyme fractions can be added to in vitro systems. This results in bio-transformation, however, with varying results depending on the compounds studied and enzymes added (Asha and Vidyavathi, 2010). The fractions contain the most common, but not all enzymes involved in biotransformation and their functioning is highly dependent on the in vitro conditions. Moreover, specific enzymes have been transfected in cell lines to study the biotransformation of compounds (Yoshitomi et al., 2001; Hashizume et al., 2009). The most suitable models to study biotransformation are primary hepatocyte cultures isolated from the rat or human liver. Human hepatocytes are particularly promising because they overcome species differences (Ullrich et al., 2009). But rat primary cultures also display active biotransformation involving phase I and II metabolizing enzymes. Under

Tab. 1: Primary cell cultures

\begin{tabular}{|c|c|c|}
\hline Advantages & Limitations & Developmental requirements \\
\hline $\begin{array}{l}\text { - Consist of mixed cell populations } \\
\text { - Comprise in vivo molecular and } \\
\text { biochemical signaling pathways } \\
\text { - 3D models reproduce more closely the } \\
\text { in vivo tissue organization } \\
\text { - 3D models have shown enhanced } \\
\text { functional properties over a prolonged } \\
\text { time frame } \\
\text { - Particularly suitable for mechanistic } \\
\text { studies } \\
\text { - Primary cell models have been } \\
\text { developed for most human organs }\end{array}$ & $\begin{array}{l}\text { - Primary cell preparations require animal } \\
\text { or human tissue } \\
\text { - Variability in mixed cell populations } \\
\text { between different cell preparations } \\
\text { - 2D monolayer cultures have a limited } \\
\text { functionality and life span } \\
\text { - 3D models have risk of central necrosis } \\
\text { due to low oxygen and nutrient supply } \\
\text { - 3D models are not always suitable for } \\
\text { standardized (96-well plate based) } \\
\text { assays } \\
\text { - Limited predictive capacity for human } \\
\text { health effects due to species differences } \\
\text { (animal tissue preparations) }\end{array}$ & $\begin{array}{l}\text { - Standardize preparation and } \\
\text { maintenance protocols to improve } \\
\text { reproducibility between cell cultures } \\
\text { - Further characterize cell models for in } \\
\text { vivo-like morphological and functional } \\
\text { properties } \\
\text { - Develop novel endpoints to exploit } \\
\text { better the third dimension in cell culture } \\
\text { - Perform validation studies to determine } \\
\text { the predictive capacity and reliability } \\
\text { of primary cell cultures for in vivo or } \\
\text { human toxicity }\end{array}$ \\
\hline
\end{tabular}


monolayer conditions, primary hepatocyte cultures often have a limited survival time and lose liver-specific functions within days (Guguen-Guillouzo et al., 2010). However, some 3D primary hepatocytes cultures have shown an increased functionality in comparison to monolayer cultures and a prolonged survival time of up to several weeks (Dash et al., 2009; Brophy et al., 2009; Tuschl et al., 2009; Mathijs et al., 2009; Wang et al., 2008). Larger scale methods are under development to produce 3D hepatocyte cultures under standardized and reproducible conditions (Miranda et al., 2010).

\subsubsection{Primary cell models reproducing the central nervous system}

Due to its complexity, it is difficult to reproduce the central nervous system (CNS) in vitro. The CNS comprises different cell populations with specific functions and cell-cell interactions (Harry et al., 1998). A variety of in vitro models with different levels of complexity are available for neurotoxicity testing (Harry and Tiffany-Castiglioni, 2005; Forsby et al., 2009). Cell lines can be useful in answering specific questions of neurotoxicity (e.g., related to a specific receptor). However, a cell line derived from a single cell type cannot cover the cell-cell interactions within the CNS. Primary cell cultures derived from brain tissues (e.g., cortex or cerebellum), however, display a large number of complex processes related to the developing and mature CNS. Studies in primary cells have demonstrated the important role of biochemical signaling between neurons, astrocytes, and microglia in mechanisms of neurotoxicity (Aschner and Kimelberg, 1991; Giordano et al., 2009) or cell survival (Kirchhoff et al., 2001). $3 \mathrm{D}$ cell models have also been developed, which are usually prepared from fetal brain tissue (rat or mouse) dissociated and spontaneously re-aggregated under rotation-mediated culture conditions (Honegger et al., 1979, 2001; Purcell et al., 2003; Vereyken et al., 2009). Aggregated brain cell cultures can be maintained for prolonged periods of time and exhibit processes of neurodevelopment (Honegger and Schilter, 1992). The 3D cultures have been extensively used to study neurotoxic mechanisms of metals and pesticides (Walker et al., 1999; Eskes et al., 2003; Zurich et al., 2004; Monnet-Tschudi et al., 1996, 2007). Recently, aggregated cultures have been combined with emerging technologies to study neurotoxicity, such as multi-electrode array-based electrophysiological recordings of neuronal activity (Uroukov et al., 2006; van Vliet et al., 2007) and metabolomics (van Vliet et al., 2008). To improve the availability of brain spheroid cultures they have been cryopreserved (Purcell et al., 2003).

\subsubsection{Primary cell models reproducing the kidney}

Besides the liver, the kidneys are a common target site of toxicity. The kidneys receive large amounts of blood and maintain body homeostasis by regulating water, electrolyte concentrations, and blood $\mathrm{pH}$-level. Because the kidneys are the major organs for the excretion of hydrophilic compounds and their metabolites, they are at high risk of exposure (Pfaller and Gstraunthaler, 1998). Renal epithelial cells of the proximal nephron are common target sites in the kidney, since they exhibit a large number of trans- port systems and metabolizing enzymes. Primary renal epithelial cell cultures have been developed that are prepared from animal or human kidney tissue samples (Brown et al., 2008). The cells are typically grown under monolayer conditions in which they form tight junctions and microvilli, and express a large number of specific cell surface markers and transporters (Baer et al., 2006). Although the primary cells gradually lose specific organ functions during culture, they currently represent the model closest to the in vivo condition. Primary renal tubular epithelial cells have been used to study the nephrotoxicity mechanisms of anti-cancer drugs (Wegner et al., 2005; Pourahmad et al., 2010; Camano et al., 2010; Li et al., 2006).

\subsubsection{Primary cell models reproducing the skin}

Perhaps the most successful three-dimensional primary cell models are those derived from the human skin. Several human reconstituted epidermis models have been developed that exhibit morphological and functional differentiation comparable to in vivo human epidermis (Tinois et al., 1991; Cannon et al., 1994; Netzlaff et al., 2005). Although the skin models were found to be more permeable compared to human skin in vivo, their permeability and toxicity response is less variable. As a result, a number of reconstituted skin models have been successfully validated for the prediction of human skin corrosion and irritancy (Alepee et al., 2010; Kandarova et al., 2006; Fentem et al., 1998). Currently, a reconstituted human skin micronucleus assay is under development for in vitro genotoxicity testing (Mun et al., 2009; Curren et al., 2006). Because the skin represents the tissue with the highest exposure after application of a cosmetic or accidental exposure to a chemical, it could be a relevant model for testing genotoxicity. An issue that still needs to be addressed for this application is the presence of in vivolike metabolic capacity in reconstituted skin models.

\subsubsection{The potential role of primary cell cultures in the vision}

Primary cell cultures currently are the most suitable in vitro models to reproduce the in vivo condition. Although several primary cell models have shown promising results in predicting mechanisms of in vivo toxicity (Forsby et al., 2009; Toh et al., 2009), very few have been formally validated. The use of primary cell cultures from animal or human tissue in the vision would be greatly supported by validation exercises that demonstrate their predictive capacity and reliability. While human stem cell applications are improving rapidly, in most cases primary cell cultures still represent the most complex and well characterized in vitro systems and are, therefore, particularly promising for the identification of toxicity pathways. Once a number of existing toxicity pathways are identified, specifically designed human cell models, which are more suitable for screening (e.g., by stem cell differentiation), could be applied to test larger numbers of compounds. The in vitro concentration of compounds that triggers toxicity pathways in human cell models could then be used to predict human tissue concentrations for risk assessment. For relevant predictions it is important that the concentrations are measured 
in the cells or tissue instead of in the external culture medium. The medium concentration could be irrelevant due to binding of the chemical to plastic or serum, or the chemical could have accumulated in the cells. Sensitive analytical methods, for example based on mass spectrometry, are required to achieve this.

\subsection{Human stem cell models}

The use of human cells to predict the impact of chemicals on human health has long been a key objective for in vitro toxicologists (Tab. 2). Due to species differences, humans and animals respond differently to chemical exposures, pointing to the need for uncertainty factors ("safety factors") during risk assessment, factors that can vary from 10-fold up to 10,000 -fold (NRC, 2000). Between animal species (rat, mouse, rabbit), toxicity studies show an agreement of about 53-60\% (Gottmann et al., 2001; Schardein et al., 1985). So far only a few studies have systematically reviewed the accuracy of animal models for the prediction of human health effects, perhaps because animal studies show a rather limited predictive capacity for human risk (Hartung and Daston, 2009). For example, a recent study demonstrated a concordance of $56 \%$ between a human skin irritation patch test and rabbit skin irritation data (Jirova et al., 2010). The promise is that human cells can predict more accurately the response of the human body to chemicals than animal cells can. Another important advantage of human cells is their potential to reveal human susceptibility factors for disease or toxicity (Chapin and Stedman, 2009).

\subsubsection{Human embryonic and adult stem cells}

The most promising current sources of human cells for toxicity testing are human embryonic, adult, or induced stem cells. The use of human embryonic stem cells for research purposes has caused an ethical and religious debate. Nevertheless, human embryonic and adult stem cells are routinely cultured in laboratories to develop in vitro test systems (Leist et al., 2008). Human embryonic stem cells are isolated from the inner cell mass of the blastocyte at the stage of embryonic development when implantation occurs (Bongso et al., 1994). The isolated cells were initially grown on a supportive feeder cell layer which provided the required nutrients and hormones, but now cells can be maintained without feeder cells by a modification of the culture medium (Ludwig et al., 2006; Navarro-Alvarez et al., 2008). Adult stem cells can be isolated from a variety of tissues in the human body such as bone marrow (Pittenger, 2008), skin (Fernandes et al., 2004), liver (Gaudio et al., 2009), cord blood (Moon et al., 2008), the heart (Smits et al., 2009), and brain (Clarke et al., 2000), where they function in tissue homeostasis and repair. Stem cells have two properties that make them particularly interesting: First, embryonic and adult stem cells show self-renewal and can in theory be grown indefinitely. Therefore they potentially provide an unlimited source of identical cells. Second, embryonic stem cells are pluripotent, meaning that they have the potential to differentiate into any functional cell type of the human body. Human embryonic stem cells have been differentiated into a variety of cell types, such as neurons (Schulz et al., 2004; Yan et al., 2005), hepatocytes (Rambhatla et al., 2003; Lavon, 2010), and cardiomyocytes (Kehat et al., 2003). Adult stem cells are usually multipotent and can be differentiated into a limited number of cell types depending on the tissue they were isolated from.

\subsubsection{Induced pluripotent stem cells}

For an easier source of stem cells and to overcome the ethical and religious issues regarding the use of embryonic stem cells, scientists have established induced pluripotent stem cells (iPSC) (Takahashi and Yamanaka, 2006). iPSC are adult somatic cells that are genetically reprogrammed to a pluripotent stem cell-like

Tab. 2: Human stem cells

\begin{tabular}{|c|c|c|}
\hline Advantages & Limitations & Developmental requirements \\
\hline $\begin{array}{l}\text { - Potential to directly predict human } \\
\text { health effects } \\
\text { - Self renewal, therefore potentially an } \\
\text { unlimited source of identical cells } \\
\text { - Differentiation towards various } \\
\text { functional human cell types } \\
\text { - Opportunity to study the influence of } \\
\text { genetic factors and susceptibility in } \\
\text { the human population } \\
\text { - Allow the study of early human } \\
\text { developmental processes } \\
\text { - Induced pluripotent stem cells } \\
\text { overcome ethical and religious issues } \\
\text { of embryonic stem cells } \\
\text { - Induced pluripotent stem cell } \\
\text { applications are improving rapidly }\end{array}$ & $\begin{array}{l}\text { - Ethical and religious issues of embryonic } \\
\text { stem cells } \\
\text { - Unclear functional and genetic stability } \\
\text { of stem cells over long time periods } \\
\text { - Difficult to obtain "pure cultures" of a } \\
\text { single or specific number of cell types } \\
\text { - Cultures contain cell populations at } \\
\text { various stages of cell differentiation } \\
\text { - Not well defined presence of in vivo cell- } \\
\text { cell interactions and signaling pathways } \\
\text { - Not well defined metabolic competence } \\
\text { of differentiated stem cells } \\
\text { - Some stem cell cultures depend on } \\
\text { the presence of feeder cells } \\
\text { - Stem cell-like properties of induced } \\
\text { pluripotent stem cells are not fully } \\
\text { characterized }\end{array}$ & $\begin{array}{l}\text { - Optimize and standardize maintenance } \\
\text { and differentiation protocols } \\
\text { - Improve monitoring of identity and } \\
\text { stability over long time periods } \\
\text { - Improve characterization of functional } \\
\text { properties and cell signaling pathways } \\
\text { - Clear definition of metabolic } \\
\text { competence } \\
\text { - Continue the development and } \\
\text { characterization of induced pluripotent } \\
\text { stem cell models } \\
\text { - Perform validation of stem cell models } \\
\text { to define their predictive capacity and } \\
\text { reliability for human toxicity }\end{array}$ \\
\hline
\end{tabular}


state (O'Malley et al., 2009). This state is induced by the overexpression of pluripotent factors such as Oct3/4, Sox2, Klf4, and c-Myc, which are responsible for maintaining the "stemness" of embryonic stem cells. Human iPSC have been generated from human fibroblasts (Yu et al., 2007). The resulting iPSC were shown to have a similar morphology, proliferation, surface antigens, gene expression, and telomerase activity as human embryonic stem cells. Moreover, they have the potential to differentiate into the cell types of the three germ layers (Yu et al., 2007). Remaining issues of concern are whether iPSC and embryonic stem cells rely on identical mechanisms to maintain pluripotency, use the same mechanisms to control cell differentiation, and display similar characteristics after differentiation. First studies show that iPSC rely on similar mechanisms to maintain pluripotency and control differentiation (Vallier et al., 2009), though some differences exist between gene expression signatures due to differential promoter binding (Chin et al., 2009). Regarding differentiation, a study comparing the neural differentiation of human iPSC and embryonic stem cells showed that both use the same network of gene expression and developmental time course to generate functionally neuronal cell types. However, significant differences were found between the efficiency and variability in cell differentiation (Hu et al., 2010). Comparison of hematopoietic and endothelial differentiation of different iPSCs obtained from fetal, neonatal, or adult human fibroblasts showed a similar differentiation pattern with some variation in efficiency (Choi et al., 2009). Although studies clearly showed similarities between iPSCs and embryonic stem cells during pluripotency and differentiation, more studies are required to compare the characteristics of differentiated cells. Human iPSC have been differentiated into functional dopaminergic neurons (Swistowski et al., 2010), hepatocytes (Sullivan et al., 2010), and cardiomyocytes (Haase et al., 2009). Thus iPSCs have great potential for toxicity testing but further characterization is required.

\subsubsection{Stem cell applications for hepatotoxicity testing}

Embryonic and adult human stem cells have been differentiated into hepatocyte-like cells that show a number of liver-specific morphological and functional characteristics, such as the expression of liver-specific genes, glycogen storage, albumin secretion, and cytochrome p450 (CYP) activity (Chivu et al., 2009; Basma et al., 2009; Baharvand et al., 2008; Hay et al., 2008; Agarwal et al., 2008). Some recent studies differentiate embryonic stem cells according to a three-step differentiation protocol, where first the definitive endoderm is formed, followed by hepatic progenitor cells, which are finally differentiated and maturated into functional hepatocyte-like cells (Soto-Gutierrez et al., 2008; Brolen et al., 2010). This differentiation procedure better represents the in vivo hepatic developmental process and the generated hepatocyte-like cells displayed improved functional characteristics (expression of liver-associated genes, proteins, and CYP enzymes). Moreover, embryonic or adult stem cell-derived hepatocytes displayed improved characteristics and metabolic functionality when grown in 3D cultures as compared to monolayer cultures (Li et al., 2010; Liu et al., 2010; Farzaneh et al., 2010). The latest developments include the generation of functional hepatic cells from human iPSC (Sullivan et al., 2010). Although, stem cell-derived hepatocytes are not able yet to fully reproduce the functional characteristics of in vivo hepatocytes, their functional properties are continuously improving. Therefore, it is expected that stem cell-derived hepatocytes will play an increasingly important role in hepatotoxicity testing (Greenhough et al., 2010; Guguen-Guillouzo et al., 2010).

\subsubsection{Stem cell applications for cardiotoxicity testing}

Certain drugs can prolong the time of the heart's ventricular depolarization and repolarization (QT interval), which is associated with life-threatening ventricular arrhythmia (Charbit et al., 2008; Cubeddu, 2003). Isolated human cardiomyocytes demonstrate in vivo characteristics and can be used to study drug-induced QT interval prolongation; however their availability is limited (Bistola et al., 2008; Bird et al., 2003). As an alternative, human embryonic stem cells have been differentiated into functional cardiomyocytes, which express numerous cardiomyocyte proteins and display spontaneous rhythmic contractions (Zhang et al., 2009; Steel et al., 2009). These contractions can be recorded in vitro using electrophysiological measurements such as conventional patch clamp or multi-electrode arrays. Studies using these technologies have shown promising results in predicting cardiac toxicity and QT prolongation for reference drugs (Braam et al., 2010; Caspi et al., 2009). Nevertheless, some challenges remain since current differentiation protocols have a limited yield of functional cardiomyocytes with variable degrees of purity. Moreover, stem cell-derived myocytes display an early and heterogeneous phenotype that differs from adult myocytes.

\subsubsection{Stem cell applications for developmental toxicity testing}

Stem cell applications have great potential for developmental toxicity testing, since stem cells reflect a high number of relevant developmental processes (Nishikawa et al., 2007; Yamashita et al., 2010). In fact, a mouse embryonic stem cell test has been formally validated for the screening of embryotoxicity (Spielmann et al., 2006). The test is based on the $\mathrm{IC}_{50}$ analysis of three endpoints, including the assessment of embryonic stem cell differentiation into beating cardiomyocytes, the assessment of cytotoxic effects on undifferentiated embryonic stem cells, and cytotoxic effects on differentiated $3 \mathrm{~T} 3$ fibroblasts. To predict the embryotoxicity of a chemical, the $\mathrm{IC}_{50}$ values of the three endpoints are put into a prediction model that allows distinctions between embryotoxic classes, i.e., strong, weak, or none in terms of potency (Genschow et al., 2000, 2004). Limitations of the validated test include the reliance on a morphological endpoint (analysis of beating cardiomyocytes) and the relatively long 10-day culture period. To overcome these limitations, a revised version of the test was developed based on flow cytometric technology, which is more suitable for screening purposes (Buesen et al., 2009). A concern in the area of developmental toxicity is the increasing incidence of developmental 
disorders in children and the potential link with chemical exposures (Schettler, 2001). Current in vivo-based test guidelines for developmental neurotoxicity are too timely and costly to test large numbers of chemicals. To develop a more efficient paradigm, embryonic and adult stem cells are extensively used to evaluate the adverse effects of chemicals on processes of neurodevelopment (Kuegler et al., 2010; Moors et al., 2009; Buzanska et al., 2009). A recent high content screening study measuring viability, proliferation, migration, and differentiation of neural progenitor cells showed promising results in prediction of in vivo developmental neurotoxicity (Breier et al., 2010).

\subsubsection{The potential role of stem cell applications in the vision}

While embryonic and adult human stem cell applications in toxicology are developing rapidly, some critical issues and challenges remain. The identity and stability of stem cell cultures often are not well defined, and cells can undergo genetic changes over time. In addition, the differentiation of stem cells generally leads to populations of cells with different phenotypes; therefore the purity of these cultures remains an issue for reliable and standardized toxicity testing. To reduce the heterogeneity of cell types in stem cell cultures, molecular techniques are applied as selective markers. Stem cells are transfected with transgenes inducing antibiotic resistance that allows the elimination of contaminating cells, or transgenes inducing fluorescence activity that allows fluorescence-based sorting of stem cell populations. In addition, the over-expression of specific transcription factors critical to cellular differentiation was found to reduce heterogeneity. The use of these methods has enhanced the purity of differentiated stem cell cultures, but further work is required (Kim et al., 2002; Hidaka et al., 2003; Chung et al., 2002). The biggest challenge of stem cell differentiation remains the achievement of in vivo-like functional characteristics. Although studies have shown promising results, the predictive value of human stem cells for human health effects has not been extensively investigated. To establish the predictive value, a coordinated validation study is required that tests a large set of reference compounds. The limiting factors for this are costs and the availability of high quality human toxicity data. The publication of the vision has strongly supported the use of human stem cells, and more than ever in vitro toxicology is focused on toxicity predictions based on human cells. In the near future, it should become clear whether human cells can provide more accurate predictions of human toxicological risk than current animal tests.

\section{Non-mammalian model organisms}

The most commonly used non-mammalian model organisms in toxicology include the roundworm (Caenorhabditis elegans), the zebrafish (Danio rerio), and the fruit fly (Drosophila melanogaster) (Tab. 3). Although these organisms are evolutionarily very distant from humans, it has become clear that they do exhibit a large number of physiological and pharmacological properties useful for toxicity testing. In addition, these models offer a more convenient alternative in terms of availability, cost, and use for high throughput applications than do mammalian organisms.

\subsection{Caenorhabditis elegans}

C.elegans is a nematode species that inhabits soil and leaf-litter environments in many parts of the world. For a number of reasons the species has become an emerging model in toxicology. This nematode is well characterized, meaning that its entire genome is sequenced, its developmental process well described, and its nervous system, which contains 302 neurons, has been completely mapped out. Many of the basic physiological processes are conserved in C.elegans, such as $60-80 \%$ of human genes and

Tab. 3: Non-mammalian organisms

\begin{tabular}{|c|c|c|}
\hline Advantages & Limitations & Developmental needs \\
\hline $\begin{array}{l}\text { - Easy availability and relatively low costs } \\
\text { - Comprise a large number of signaling } \\
\text { pathways relevant for human toxicity } \\
\text { - Genomes have been sequenced } \\
\text { and different genotypes have been } \\
\text { developed } \\
\text { - Transparency of embryos allows } \\
\text { visualization of rapid development } \\
\text { - Transparency of embryos allows } \\
\text { the use of reporter gene imaging } \\
\text { (including real-life) } \\
\text { - Suitable for sorting and high throughput } \\
\text { testing in multi-well plates } \\
\text { - Simultaneous application of molecular } \\
\text { and behavioral endpoints to identify } \\
\text { potential links }\end{array}$ & $\begin{array}{l}\text { - Not well defined predictive capacity for } \\
\text { in vivo or human toxicity } \\
\text { - Pharmacokinetic differences compared } \\
\text { to the in vivo and human situation } \\
\text { - Not well defined metabolic competence } \\
\text { - Unclear internal dose of the test } \\
\text { compound after external exposure }\end{array}$ & $\begin{array}{l}\text { - Improve characterization of metabolic } \\
\text { competence } \\
\text { - Determine accurate internal doses } \\
\text { (concentrations) after external exposure } \\
\text { - Perform validation studies to define } \\
\text { the predictive capacity and reliability of } \\
\text { non-mammalian model organisms for } \\
\text { in vivo and human toxicity }\end{array}$ \\
\hline
\end{tabular}


most of the human signal transduction pathways (NRC, 2000; Kaletta and Hengartner, 2006). This makes C. elegans a valuable model for the discovery of toxicity pathways. An important advantage is that molecular endpoints such as knock-out mutants, RNA interference, and reporter proteins can be combined with behavioral endpoints including feeding, locomotion, habituation, reproduction, and memory (Boyd et al., 2007; Dhawan et al., 1999; Giles and Rankin, 2009). Such studies can provide useful information regarding the function of genes, proteins, and signaling pathways. Because $C$. elegans can be sorted over 96-well plates, high throughput screening and high content imaging applications have been developed that evaluate behavior, reporter gene, and fluorescent protein expression (O'Rourke et al., 2009; Helmcke et al., 2010). C. elegans has been a useful model in various areas of toxicology, including neurotoxicity (Xing et al., 2009; Helmcke et al., 2009; Cole et al., 2004; Jadhav and Rajini, 2009), genotoxicity (Astin et al., 2008), and ecotoxicology (Leung et al., 2008). A study showed that the toxicity of pesticides in $C$. elegans correlates well with $\mathrm{LD}_{50}$ values in mice and rats (Cole et al., 2004). Moreover, assays in C. elegans were shown to predict neurological and developmental toxicity in mammalian species (Anderson et al., 2004; Williams et al., 2000). Therefore, $C$. elegans could potentially provide a more cost- and timeefficient alternative to some mammalian-based tests.

\subsection{Danio rerio}

The zebrafish (Danio rerio) has become an increasingly popular model organism in toxicology for a number of reasons. The zebrafish exhibits molecular mechanisms of development and cellular physiology similar to mammals (Kari et al., 2007). Fertilization and development occur externally, and a pair of zebrafish can produce 100-300 eggs per week, making zebrafish embryos a suitable model for high throughput screening. The embryos are transparent, can be maintained in 96- or 384-well plates, and undergo a rapid developmental process, e.g., embryogenesis is completed after 5 days. Their transparency allows easy developmental staging, as well as the study of embryonic and teratogenic effects of chemicals and drugs (Yang et al., 2009). Also, in situ hybridization and immunochemistry techniques have been developed to screen for chemical-induced effects on gene and protein expression. The zebrafish has been used to study various chemicals including metals, PCBs and pesticides, and an extensive overview of toxicity studies is provided by Hill et al. (2005). Some recent studies focus on neurotoxicity, applying high throughput biochemical, molecular, and neurobehavioral endpoints (Fan et al., 2010; Parng et al., 2007; Eddins et al., 2010). Furthermore, non-invasive methods to screen for cardiac toxicity have been developed (Burns et al., 2005; Chan et al., 2009). A recently published review summarizes and describes the overall promising predictive capacity of zebrafish studies for drug toxicity (Eimon and Rubinstein, 2009).

\subsection{Drosophila melanogaster}

The fruit fly (Drosophila melanogaster) is inexpensive, easy to maintain, and conserves some fundamental human cellular and developmental mechanisms. The life cycle and development of the fruit fly have been well characterized, including the formation of the central nervous system (Truman and Bate, 1988; Truman, 1990). The fly has been used as a model to study neurodegenerative disease and its drug discovery (Bilen and Bonini, 2005; Lu, 2009; Nichols, 2006). Testing adult or developmental neurotoxicity also seems particularly promising (Peterson et al., 2008; Rand, 2010). A number of endpoints can be measured in the fruit fly that provide information on toxicity, such as lethality, adult morphology, behavior, and reporter gene or protein expression. The adverse effects of methyl mercury and lead on neural development have been studied (Morley et al., 2003; Rand et al., 2009). Because the genetic components of complex behavior, memory, and learning are understood in the fruit fly, it allows the establishment of specific phenotypes for screening strategies (Sokolowski, 2001). Using different genetic phenotypes, molecular endpoints, and behavioral assays, genetic susceptibility for chemical toxicity can be studied, as performed for arsenic (Ortiz et al., 2009). The fruit fly embryo can be sorted over 96-well plates based on size, shape, or fluorescence intensity useful for high throughput screening (http:// www.unionbio.com). Using reporter genes and the injection of small interfering RNA, a screening system could be developed to identify the genes underlying toxicity pathways.

\subsection{The potential role of non-mammalian model systems in the vision}

Because a large number of human genes and signal transduction pathways were shown to be conserved in non-mammalian model organisms, they could play a significant role in the vision. Due to the transparency of some non-mammalian models, signaling pathways can be carefully studied and quantified in living organisms using reporter genes and proteins. Moreover, using gene silencing or knock-out technologies, the function of specific genes and proteins in toxicity pathways could be identified. An advantage of non-mammalian organisms is that molecular and biochemical endpoints can be complemented with behavioral endpoints, which assess the final phenotypic outcomes of toxicity pathways. Non-mammalian organisms are also suitable for high throughput screening and applications based on C.elegans and $D$. rerio are already part of the EPA ToxCast program. The ToxCast data should provide more insight into the predictive capacity of non-mammalian models for in vivo and human toxicity, since this remains a concern for their potential use. In addition, their metabolic capacity requires further characterized and accurate internal concentration levels to be established after environmental exposure to perform PBPK modeling.

\section{High throughput technologies}

High throughput systems (Tab. 4) have developed rapidly over the last years, and the latest systems are fully automated, meaning they prepare, incubate, and analyze large numbers of plates simultaneously. Plate formats (384-, 1536- or 3456-well) have been optimized to increase the number of compounds and con- 
centrations that can be tested. A high throughput system can now test thousands to more than a million samples a day. Initially, high throughput systems were used by pharmaceutical industry as a screening step in drug lead discovery (Mishra et al., 2008; Carlson and Fisher, 2008). But they are increasingly applied in toxicology to screen large numbers of compounds for specific mechanisms (Morisseau et al., 2009). There are some clear differences between toxicity testing and drug discovery applications. Drugs are designed to have a specific biological activity, cover a relatively small chemical space, and their metabolism is generally well characterized. In contrast, chemicals can have various biological activities (or none), cover a large chemical space, and their metabolism is often unclear. Moreover, drug discovery is focused on confidence in positive results or "hits," while toxicology has to focus on high confidence in negative results, because false negatives are not acceptable.

\subsection{High throughput toxicity testing}

In toxicology, high throughput testing can be used as a bottom-up or top-down approach (Houck and Kavlock, 2008). In the bottomup approach, a single or small number of chemicals are tested in a large number of assays to identify key toxicity pathways. In the top-down approach, a large number of chemicals are tested in a small number of assays to identify a similar mode of action (e.g., endocrine disrupting compounds interacting with estrogen receptors). In practice, a compromise is often created to test the maximum number of chemicals in a large number of relevant assays. To generate relevant high quality data requires an appropriate biological test system. Immortalized cell lines can be used to address specific targets, such as receptor-mediated pathways or signal transduction pathways. But more complex systems, such as differentiated stem cells, primary cells, and non-mammalian organisms are increasingly used because they often provide more relevant information for toxicity predictions (Fernandes et al., 2009). Endpoints for high throughput toxicity testing are fre- quently based on molecular targets such as signal transduction, nuclear and membrane receptor binding, ion channel activation, enzyme activity, apoptosis, oxidative stress, cell proliferation, DNA recombination, and cell cycle (Schoonen et al., 2009). New targets under development include drug transporters, proteinprotein interactions, protein-RNA interactions, and protein DNA interactions (Mayr and Bojanic, 2009). In particular, reporter gene assays are applied, in which a fluorescent reporter gene is added to a gene of interest in the biological system (Ullmann et al., 2008; Liu et al., 2009). The assay allows the sensitive detection of gene expression alterations after a chemical exposure.

\subsection{The EPA ToxCast program}

A proof-of-principle study to apply high throughput screening for toxicological risk assessment is currently being performed by the EPA ToxCast program (Dix et al., 2007). The program aims to develop a cost- and time-efficient approach to predict the potential toxicological risks of environmental chemicals for human health. In the first phase, a battery of in vitro high throughput assays and cell-based assays was used to test over 300 well-characterized chemicals (mostly pesticides) in more than 400 endpoints (Judson et al., 2010). The data showed that the activity of environmental chemicals ranges from none to effects on dozens of molecular pathways. Furthermore, the assays were able to confirm multiple mechanisms of action for well-known environmental chemicals. An initial data analysis found a significant inverse association between in vitro concentrations perturbing pathways and the lowest in vivo doses causing toxicity. This shows the first potential of using in vitro high throughput assays to predict in vivo toxicity. However, further data analysis is required to confirm this hypothesis and to evaluate the predictive capacity of the in vitro data for human health effects. To facilitate this, the data has been incorporated into the public database ToxRefBD, which provides easy access for scientists in the field of data mining and computational mod-

Tab. 4: High throughput technologies

\begin{tabular}{|c|c|c|}
\hline Advantages & Limitations & Developmental needs \\
\hline $\begin{array}{l}\text { - High testing capacity and relatively low } \\
\text { cost per tested compound or performed } \\
\text { test } \\
\text { - Standardized test conditions } \\
\text { - Reproducibility and robustness of the } \\
\text { data } \\
\text { - Application of reporter gene assays } \\
\text { - Possibility to determine reversibility } \\
\text { - Allows the generation of sensitive dose- } \\
\text { response models by testing a large } \\
\text { number of concentrations }\end{array}$ & $\begin{array}{l}\text { - Elaborate analysis and interpretation of } \\
\text { the large datasets generated } \\
\text { - Testing is often based on cell lines, } \\
\text { which lack the complexity of the in vivo } \\
\text { or human situation. } \\
\text { - Cells used often have a limited metabolic } \\
\text { competence } \\
\text { - Technical and logistic limitations for the } \\
\text { use of more complex cell models } \\
\text { - High costs of high throughput } \\
\text { technologies } \\
\text { - Test systems need to be well } \\
\text { characterized before high throughput } \\
\text { testing is performed to guarantee high } \\
\text { quality data generation }\end{array}$ & $\begin{array}{l}\text { - Need for improved data analysis and } \\
\text { interpretation methods } \\
\text { - Use more complex cell or non- } \\
\text { mammalian models that comprise } \\
\text { relevant in vivo signaling pathways } \\
\text { - Include metabolic competence } \\
\text { - Develop high throughput testing based } \\
\text { on human cells to define predictive } \\
\text { capacity for human health effects } \\
\text { - Characterize identity, purity and stability } \\
\text { of test compounds } \\
\text { - Need for availability of quality data in } \\
\text { public databases for analysis and risk } \\
\text { assessment }\end{array}$ \\
\hline
\end{tabular}


eling. In a second phase, a set of additional compounds will be tested to confirm and further evaluate the signatures of toxicity predicted in phase one.

\subsection{The potential role of high throughput testing in the vision}

High throughput testing is an important technology to make the vision feasible. Although test systems are already generating highly relevant data, there are a number of issues that still require attention. Since certain chemicals require biotransformation to be toxic, the inclusion of vivo-like metabolic capacity is of critical concern. Moreover, test chemicals need to be controlled for long-term stability and purity to guarantee their chemical and toxicological properties. The greatest challenge, however, is the development of improved data analysis and interpretation methods that preferably implement in silico and pharmacokinetic parameters. To support this, high-quality toxicity data should become available in public databases (e.g., as with the ToxCast data). In particular, data on a wide range of concentrations is useful to establish robust dose-response relationships, as current risk assessment is often based on a limited number of doses to minimize costs and animal numbers. Moreover, high throughput testing has great potential for the initial prioritization of chemicals (e.g., toxic versus non-toxic) as part of an integrated testing strategy. Such strategies could tackle the existing backlog of untested chemicals and the future test requirements for the REACH legislation (Hartung, 2010).

\section{Imaging technologies}

The latest imaging technologies allow the non-invasive visualization of molecular, biochemical, and cellular processes in living cells or small animals (Morris, 2010). Besides confirming the occurrence of these processes, imaging can provide valuable insight into their spatial and temporal dynamics (Du et al., 2006). Therefore imaging can complement genomics, proteomics, and metabolomics studies, adding valuable information to the systems biology approach (Lee and Li, 2009). Other important aspects of progress include the automation and digitization of imaging technologies (Niederlein et al., 2009).

\subsection{Molecular imaging technologies}

The two main approaches for optical-based molecular imaging are fluorescence imaging and bioluminescence imaging (Tab. 5), (Gheysens and Mottaghy, 2009; Luker and Luker, 2008a). Fluorescence imaging is based on fluorescent labeling of specific targets in a biological system using dyes, probes, or proteins. Labeling techniques have expanded rapidly, creating many opportunities to study cell structures, messenger molecules, enzymatic activities, or protein functions (Suzuki et al., 2007; Fernandez-Suarez and Ting, 2008). Molecular techniques include the introduction of genetically encoded fluorescent proteins, such as green fluorescent protein (GFP) isolated from the jellyfish Aqueorea victoria (Chalfie et al., 1994). Endogenous GFP expression can be used to localize and quantify proteins in

Tab. 5: Molecular imaging technologies

\begin{tabular}{|c|c|c|}
\hline Advantages & Limitations & Developmental needs \\
\hline $\begin{array}{l}\text { - Allows non-invasive studies in living } \\
\text { cells or organisms } \\
\text { - Sensitive and quantitative measurement } \\
\text { - Large spectrum of available fluorescent } \\
\text { probes incl. dyes, antibodies and } \\
\text { proteins } \\
\text { - Near infrared probes allow in vivo } \\
\text { studies } \\
\text { - Bioluminescence does not require an } \\
\text { excitation wavelength } \\
\text { - Multiple luciferase enzymes can be } \\
\text { used to image several structures or } \\
\text { processes } \\
\text { - Bioluminescence can be used to track } \\
\text { cells or processes over time in vitro } \\
\text { and in vivo } \\
\text { - Bioluminescence has a high signal- } \\
\text { to-noise ratio due to the inherently low } \\
\text { background } \\
\text { - Fast and relatively inexpensive } \\
\text { - Potential to reduce animal use by } \\
\text { studying a single animal extensively } \\
\text { over time }\end{array}$ & $\begin{array}{l}\text { - Fluorescent imaging requires an } \\
\text { excitation wavelength } \\
\text { - In vivo applications are dependent on the } \\
\text { penetration of light through tissue } \\
\text { - Limited by light scattering (auto } \\
\text { fluorescence) in tissue and } \\
\text { photobleaching } \\
\text { - Potential adverse effects induced by } \\
\text { fluorescent dyes, probes, or proteins. } \\
\text { - Bioluminescence requires the stable } \\
\text { transfection of luciferase reporter genes } \\
\text { - Bioluminescence is dependent on } \\
\text { presence of oxygen and ATP } \\
\text { - Luciferase is repressible by iron } \\
\text { - Limited reproducibility between } \\
\text { experiments }\end{array}$ & $\begin{array}{l}\text { - Compare in vitro and in vivo imaging } \\
\text { data to validate biological processes } \\
\text { - Develop methods to integrate imaging } \\
\text { data into the systems biology approach } \\
\text { - Further explore in vitro bioluminescence } \\
\text { imaging applications } \\
\text { - Control the potential adverse effects of } \\
\text { fluorescent labeling or transfection of } \\
\text { luciferase reporter genes in biological } \\
\text { systems }\end{array}$ \\
\hline
\end{tabular}


living cells or animals. Moreover, GFP can be fused or tagged to a protein to study its functional behavior. GFP labeling has been used to visualize various cell structures such as the plasma membrane, mitochondria, cell nucleus, Golgi apparatus, and endoplasmic reticulum. A concern for protein tagging is that the original location or functional behavior of the protein could be altered (Swedlow and Platani, 2002). Therefore, it is important to control for artifacts. In vivo imaging is mostly limited by the penetration and scattering of light in tissue (Frangioni, 2003). To overcome this, near-infrared fluorescent imaging techniques have been developed (Ntziachristos et al., 2003; Pauli et al., 2009). Light near the infrared range (700-1000 nm) penetrates deeper into tissue and has a reduced auto-fluorescence (Klohs et al., 2008).

Bioluminescence imaging is based on the production of visible light by an enzymatic reaction of luciferase with its substrate luciferin (Luker and Luker, 2008b). The approach has been used to detect, localize, and quantify biological processes in living cells or small animals (Sadikot and Blackwell, 2005, 2008). The most commonly used luciferase for in vivo molecular imaging is that of the firefly (Photinus pyralis) (Oba et al., 2003). To visualize the expression of luciferase enzymes in transgenic animals, they are injected with a non-toxic luciferin substrate, which distributes throughout the animal and passes the blood brain barrier (Luker et al., 2002). In vivo imaging has been used to study disease progress such as infection (Luker and Luker, 2010) and cancer (Lee et al., 2010). Moreover, bioluminescence imaging was used to study the viability, proliferation, migration, and differentiation of stems cells in vitro (Kammili et al., 2010; Logeart-Avramoglou et al., 2010) and after transplantation in vivo (Wilson et al., 2008). The applications for toxicity testing have been limited so far. Examples include the evaluation of chemical induced toxicity in transgenic mice expressing luciferin (Malstrom et al., 2004) and the monitoring of luciferase expression in C. elegans exposed to sub-lethal cadmium concentrations (Lagido et al., 2009). Both studies confirmed the value of bioluminescence imaging as an endpoint for toxicity evaluations.
Bioluminescence assays are also used to provide information on pharmacokinetic parameters (Cali et al., 2008). Luciferease reporter assays can detect chemical-induced effects on gene encoding drug-metabolizing enzymes and drug transporters. Moreover, the respective enzyme activities (e.g. CYP) can be monitored using inactive luminogenic substrates, which are converted by the enzymes to free luciferin substrates.

\subsection{High content imaging technologies}

High content imaging technologies combine the efficiency of high throughput systems with the sensitive and quantitative properties of molecular imaging (Tab. 6), (Zanella et al., 2010). The technologies are mostly based on automated multicolor fluorescent microscopy, which provides many opportunities due to the large spectrum of fluorescent labeling techniques (Giuliano et al., 2006). The images are analyzed by sophisticated algorithms that quantify multiple parameters and identify unusual phenotypes. Examples of common applications include the quantity of parameters related to cell signaling pathways, receptor internalization, protein expression, cell cycle status, post-translational protein modifications, cytoskeleton integrity, energy metabolism, morphology, cell movement, and cell differentiation (Houck and Kavlock, 2008). High content imaging technologies are increasingly applied in toxicology and have great potential to facilitate the identification of toxicity pathways (Zock, 2009). The combination of high content imaging with molecular techniques (e.g. gene silencing by siRNA technologies), in particular, can provide information on the role of genes and proteins in cellular pathways (Carpenter and Sabatini, 2004). Examples of applications in toxicology include the quantification of cell death indicators to prioritize compounds based on human hepatotoxicity potential (Abraham et al., 2008), imaging of micronucleus in CHO-K1 cells to predict genotoxicity (Diaz et al., 2007), and the quantification of neurite outgrowth to predict developmental neurotoxicity potential (Radio et al., 2008). A first evaluation of high content imaging data to predict human toxicity was per-

Tab. 6: High content imaging technologies

\begin{tabular}{|c|c|c|}
\hline Advantages & Limitations & Developmental needs \\
\hline $\begin{array}{l}\text { - Allows non-invasive studies } \\
\text { - Automated analysis of multiple } \\
\text { parameters } \\
\text { - Image analysis software generates } \\
\text { multiple quantitative parameters } \\
\text { - Large spectrum of available fluorescent } \\
\text { dyes, probes and proteins } \\
\text { - Availability of fluorescent reporter } \\
\text { proteins } \\
\text { - RNA silencing technologies can } \\
\text { be applied to validate cellular and } \\
\text { molecular processes }\end{array}$ & $\begin{array}{l}\text { - Limitations regarding imaging data } \\
\text { analysis and interpretation } \\
\text { - Fluorescent labeling of large cell } \\
\text { quantities can be laborious } \\
\text { - Reproducibility between experiments } \\
\text { - Not yet suitable for real-time live imaging } \\
\text { - Relatively high costs of automated } \\
\text { imaging systems }\end{array}$ & $\begin{array}{l}\text { - Need for methods to simplify fluorescent } \\
\text { labeling } \\
\text { - Improve image analysis algorithms and } \\
\text { data interpretation methods } \\
\text { - Transfer imaging data to public } \\
\text { databases } \\
\text { - Develop high content living cell imaging } \\
\text { technologies } \\
\text { - Generate more mechanistic toxicity } \\
\text { data using gene knock-out or silencing } \\
\text { techniques } \\
\text { - Develop methods to integrate imaging } \\
\text { data into the systems biology approach }\end{array}$ \\
\hline
\end{tabular}


formed. Results of a high content screening assay evaluating cell number, nuclear area, and plasma membrane permeability in human hepatocytes were compared to those of seven conventional cytotoxicity endpoints used in industry to evaluate the human hepatotoxicity potential of drugs (O'Brien et al., 2006). The data of over 600 compounds showed a higher sensitivity (93\%) and specificity (98\%) for the high content assay compared to the conventional assays (25\% and 90\%). Additional comparative studies are required to further demonstrate human predictive capacity. To improve predictive capacity, more complex human or non-mammalian models should be used. Already, screening strategies are under development that study molecular pathways and behavior in C.elegans (Cronin et al., 2006) or zebrafish larvae (Creton, 2009). Other challenges include imaging of living cells, improvement of image analysis software, and setting up public databases to make maximum use of the generated information.

\subsection{The potential role of imaging technologies in the vision}

Molecular imaging techniques allow the non-invasive study of biological processes in (living) cells and small mammals. Because imaging can provide quantitative, temporal, and spatial information on biological processes, it adds valuable information to the systems biology approach. Imaging can complement data generated by omics technologies, which provide a "snapshot" analysis at a certain time point. For the vision imaging could help to define adversity by evaluating parameters related to toxicity pathways and phenotypic characteristics. The determination of adversity remains an issue for the proposed toxicity pathway-based approach, since a perturbation does not automatically lead to adverse health effects. Adversity occurs only if a perturbation is strong enough and the system can no longer adapt. Imaging could potentially reveal the dynamic transition from adaptation to adversity. Combining imaging with behavioral studies creates the opportunity to link molecular processes to behavioral changes. Moreover, imaging could improve the scientific basis of animal models and reduce the number of animals required. The increase in data gained by performing noninvasive imaging at multiple time points in the same animal (each animal acts as its own control) will allow better statistics, providing more confidence in results.

\section{Omics technologies}

Omics technologies have the goal of analyzing the components of a living system in its entirety (Evans, 2000). The omics field falls into various subdivisions, depending on the cellular component being measured, including the genome, transcriptome, proteome, and metabolome. The number of omics-related publications has increased rapidly over the last years - in particular, the number of reviews describing the potential of omics applications in various scientific fields, including drug discovery (Butcher et al., 2004), personalized medicine (Tanaka, 2010), food science (Trujillo et al., 2006), and toxicology (Aardema and MacGregor, 2002).

\subsection{Genomics}

The field of genomics investigates genome structure and function in biological systems (Tab. 7) (McKusick, 1997). Genomics studies focused on identifying genome structure apply DNA sequencing technologies. The first DNA sequencing methods were established in the 1970s (Sanger et al., 1977). Since then, sequencing technologies have developed substantially, and today high throughput DNA sequencing technolo-

\section{Tab. 7: Genomics}

\begin{tabular}{|c|c|c|}
\hline Advantages & Limitations & Developmental needs \\
\hline $\begin{array}{l}\text { - High throughput sequencing techniques } \\
\text { allow the cost and time efficient } \\
\text { sequencing of complete genomes } \\
\text { - Study of polymorphisms can give insight } \\
\text { into the role of genetics in toxicology } \\
\text { and explain differences in susceptibility } \\
\text { - Gene arrays allow the simultaneous } \\
\text { gene expression analysis of thousands } \\
\text { of genes } \\
\text { - Availability of gene arrays with complete } \\
\text { genomes including the human } \\
\text { - Sensitive endpoint of toxicity since gene } \\
\text { expression changes often occur at an } \\
\text { early stage }\end{array}$ & $\begin{array}{l}\text { - Genome sequencing alone is not enough } \\
\text { since polymorphisms play an important } \\
\text { role } \\
\text { - Alterations in gene expression do not } \\
\text { always lead to adverse health effects } \\
\text { - Gene array analysis can overlook modest } \\
\text { changes in gene expression } \\
\text { - Limited reproducibility between gene- } \\
\text { array experiments } \\
\text { - Gene arrays are semi-quantitative and } \\
\text { data needs confirmation by quantitative } \\
\text { techniques } \\
\text { - Often difficult to translate genomics } \\
\text { results to in vivo or human toxicity or } \\
\text { disease } \\
\text { - Genomics often requires proteomics and } \\
\text { metabolomics follow-up studies }\end{array}$ & $\begin{array}{l}\text { - Develop improved data analysis and } \\
\text { interpretation methods for gene array } \\
\text { data } \\
\text { - Link related genes to cellular pathways } \\
\text { - Integrate genomics data with proteomics } \\
\text { and metabolomics data in the systems } \\
\text { biology approach } \\
\text { - Identify genes that can be used as early } \\
\text { biomarkers for toxicity } \\
\text { - Need for quality gene expression data } \\
\text { in public databases }\end{array}$ \\
\hline
\end{tabular}


gies can generate up to billions of small sequence reads per run at relatively low costs (Schuster, 2008; Mardis, 2008). So far, the entire genomes of over 180 organisms were sequenced (http://www.genomenewsnetwork.org), including the human genome by the Human Genome Project (Collins et al., 2003). The comparison of genome structure across species or individuals in a population can give insight into genetic variation. The most frequent variation is due to single nucleotide polymorphisms (SNPs), which comprise a substitution, deletion, or insertion of a single nucleotide to a polynucleotide chain (Kim and Misra, 2007). Genetic variation has the potential to determine how individuals develop diseases or respond to therapeutic treatments. Moreover, it can help determine susceptibility towards chemical-induced toxicity (Thomas et al., 2002; Garte et al., 2008).

Despite extensive knowledge of genome structures, much remains unknown about the expression, regulation, and function of many protein-encoding genes. Therefore, functional genomics, which aims to identify the functions and interactions of genes within a genome, has received much attention (Hieter and Boguski, 1997). Transcriptomics is an important part of functional genomics and applies gene microarray technologies to simultaneously measure the expression of several thousand genes (Duggan et al., 1999; Schena et al., 1995). The two main types of microarrays include DNA and oligonucleotide-based arrays (Katagiri and Glazebrook, 2009). DNA arrays contain complementary DNA and are based on the hybridization reaction of DNA with its complementary mRNA strand. Although these arrays are sensitive, they are limited by the preparation of high-quality cDNA probes. To overcome this, oligonucleotide arrays based on the synthesis of oligonucleotide probes have been developed (Lockhart et al., 1996). The easy synthesis of probes led to custom-made arrays that can contain the majority of an organism's mRNA species, including that of humans (Kronick, 2004). Gene array data is analyzed using computational and statistical methods to identify differences in gene expression patterns and functional relationships between genes. For mechanistic studies, the expression of specific genes is usually further analyzed by real-time quantitative PCR (Walker, 2001). Transcriptomics is particularly promising for toxicology, since toxicity generally involves not the alteration of a single gene but a cascade of gene interactions (Aardema and MacGregor, 2002).

\subsubsection{Toxicogenomics}

Toxicogenomics aims to investigate the interactions between the genome and adverse biological effects induced by toxic compounds (Gatzidou et al., 2007). Genomic information can play an important role in understanding or predicting the toxicity response of a biological system (Thomas et al., 2002). The genomic sequence can significantly affect the pharmacokinetics of a compound in a biological system and thereby its susceptibility (Ferrer-Dufol and Menao-Guillen, 2009). In particular, the expression of genes involved in biotransformation, such as cytochrome p450 enzymes, can play an important role (Bozina et al., 2009).
Gene expression can rapidly change in response to toxic exposure, and several studies have demonstrated gene expression profiling to be a sensitive endpoint for toxicity (for example, acetaminophen-induced gene expression alterations in rat liver at doses considered non-toxic by conventional clinical endpoints (Heinloth et al., 2004) and chemical- and pesticideinduced gene expression alterations in a primary neuronal cell model at concentrations not effecting cell viability (Hogberg et al., 2009, 2010)). Such alterations in gene expression have the potential to provide insight into toxicity pathways. Using statistical methods (e.g., clustering techniques), genes with common expression patterns can be identified, assuming they are functionally related in a network. Moreover, gene knockout or silencing techniques, such as small interfering RNA (siRNA) (Elbashir et al., 2002), can be used to verify the function or relation of a gene in a network (Walgren and McLeod, 2005).

Besides mechanistic information, gene expression profiling has been applied to predict toxicity or classify chemicals into different toxicity classes (Maggioli et al., 2006). Gene expression patterns induced by reference compounds can be used as a "fingerprint" to predict the toxicity of unknown chemicals. Often, a set of discriminatory genes is applied to assigned chemicals to different toxicity classes, e.g., based on potency or mechanism. Gene expression-based classification studies have been used to discriminate between genotoxic and non-genotoxic carcinogens (van Delft et al., 2005) or hepatotoxicants and non-hepatotoxicants (Zidek et al., 2007) and to predict the carcinogenic potential (Waters et al., 2010) or developmental toxicity of chemicals (van Dartel et al., 2010a,b). The major drawback of toxicogenomics is that it depends on the assumption that mRNA levels reflect protein levels in a biological system. Therefore, studies are often complemented by proteomics and metabolomics approaches to investigate what happens further downstream.

\subsection{Proteomics}

Proteomics involves the comprehensive study of proteins, including quantitative measurement of protein expression, the study of protein structures, and protein-protein interactions (Tab. 8) (Blackstock and Weir, 1999; James, 1997). Proteomics studies are more complex than genomics because a biological system contains about $1,000,000$ proteins in comparison to the estimated 25,000 protein-encoding genes. In addition, protein expression differs from cell to cell, and there are a number of post-translational modifications that can change protein function (Mann and Jensen, 2003).

The conventional platform for proteomics studies is 2-dimensional (2D) gel electrophoresis combined with mass spectrometry analysis. The approach separates the protein mixture in a gel based on isoelectric point and mass, visualizes the protein spots using a staining, and compares the quantity of protein spots in two or more gels by imaging software. Specific spots (often containing several proteins) can be cut out of the gel for identification using matrix-assisted laser desorption/ionization mass spectrometry. Although 2D gel electrophoresis is 
frequently applied, it is not very suitable for highly acidic or basic proteins or proteins of low abundance. Moreover, there are reproducibility issues between runs, making it difficult to combine or compare data from different studies (Garbis et al., 2005). To overcome these limitations, isobaric tag for relative and absolute quantification (iTRAQ) proteomics has been developed, which makes use of isobaric labels and tandem electrospray ionization (ESI) mass spectrometry (Ross et al., 2004). The method allows the analysis of up to eight protein samples, each labeled with a specific isobaric tag. The tags bind to amine residues of proteins and have an identical mass when detected by ESI mass spectrometer. Upon MS fragmentation, however, the tags release their specific reporter ions and the eight protein samples can be distinguished. The intensities of the reporter ions allow protein quantification, and the specific peptide fragment ions in the mass spectra can be compared to a database for protein identification. Protein arrays are increasingly applied in the field of proteomics because they provide a sensitive, rapid, and cost-effective screening tool for protein analysis (Stoevesandt et al., 2009). The main types of protein arrays include functional, analytical, and reverse phase arrays. Functional arrays contain immobilized proteins and are used to study protein interactions with DNA, other proteins, or small molecules (Merkel et al., 2005). Analytical assays contain affinity agents such as antibodies, antigens, DNA, or small molecules, and they are primarily used to measure protein expression in complex protein samples (Phizicky et al., 2003). Finally, reverse phase arrays contain cell lysates or protein samples, which are probed with labeled antibodies to study protein expression, protein modifications (e.g. phosphorylation), or protein signaling networks (VanMeter et al., 2007).

\subsubsection{Proteomics applications for toxicity testing}

Proteomics studies in the field of toxicology have focused mainly on the identification of biomarkers and the refinement of mechanistic understanding of molecular mechanisms of toxicity (Kennedy, 2002). Studies based on animal models analyze the global protein expression in tissue, blood, or urine samples. A large number of studies have been performed by the pharmaceutical industry to identify biomarkers for liver and kidney toxicity (George et al., 2010; Wetmore and Merrick, 2004). The analysis of human blood and urine samples is particularly promising for the prediction of human toxicity. Protein profiling in these samples provided relevant information regarding an individual's health status (Cho et al., 2008; Thongboonkerd, 2008). Currently, the human blood plasma proteome is being mapped to gain more insight into disease and toxicity (Omenn et al., 2009). Proteomics analysis is increasingly applied in vitro, including applications based on stem cells (van Hoof et al., 2008). Until now, studies have focused mainly on gaining mechanistic insight into the molecular basis of stem cell differentiation, e.g., into neurons and glial cells (Chaerkady et al., 2009), hepatocytes (Li et al., 2009), or cardiomyocytes (Wen et al., 2007). However, a recent proteome profiling study defined a set of protein biomarkers for embryotoxicity in embryonic stem cells (Osman et al., 2010). Other in vitro proteomics studies have investigated mechanisms of toxicity in primary cell cultures. Examples include the role of protein phosphorylation in methyl mercury chloride neurotoxicity (Vendrell et al., 2010), the developmental toxicity of selenium (Usami et al., 2008), and sodium lauryl sulfate induced skin irritation (Fletcher and Basketter, 2006). Moreover, the hepatotoxicity of several reference compounds was studied in rat primary hepa-

\section{Tab. 8: Proteomics}

\begin{tabular}{|c|c|c|}
\hline Advantages & Limitations & Developmental needs \\
\hline $\begin{array}{l}\text { - Important role of proteins in cell } \\
\text { homeostasis } \\
\text { - Quantitative analysis } \\
\text { - 2D gel electrophoresis is routinely } \\
\text { applied } \\
\text { - iTRAQ simplifies quantitative } \\
\text { measurements of a protein mixture } \\
\text { - MS-based approaches allow the } \\
\text { identification of proteins } \\
\text { - Sensitivity, specificity and low costs } \\
\text { of protein arrays } \\
\text { - Protein arrays allow the simultaneous } \\
\text { analysis of thousands of proteins } \\
\text { - Analysis of protein-protein interactions } \\
\text { - Protein profiling can be performed } \\
\text { in cells, tissues and non-invasively in } \\
\text { body fluids (blood plasma, serum) } \\
\text { - Shown to generate protein biomarkers } \\
\text { for in vivo toxicity }\end{array}$ & $\begin{array}{l}\text { - Complexity and instability of the } \\
\text { proteome } \\
\text { - Large number of proteins and possible } \\
\text { posttranslational modifications } \\
\text { - Limited detection of low abundance and } \\
\text { highly acidic or basic proteins by 2D gel } \\
\text { electrophoresis } \\
\text { - Limited reproducibility between 2D gel } \\
\text { electrophoresis experiments } \\
\text { - Not all proteins in a sample can be } \\
\text { identified } \\
\text { - Limited availability of antibodies for } \\
\text { the detection of the large amounts of } \\
\text { existing proteins }\end{array}$ & $\begin{array}{l}\text { - Apply proteomics approaches to study } \\
\text { mechanisms of toxicity in vitro } \\
\text { - Map the human proteome including } \\
\text { human protein functions } \\
\text { - Develop improved data analysis and } \\
\text { interpretation methods } \\
\text { - Standardize methods to allow data } \\
\text { exchange and comparison } \\
\text { - Integrate data with genomics and } \\
\text { metabolomics data into a systems } \\
\text { biology approach } \\
\text { - Annotate proteomics data in public } \\
\text { databases } \\
\text { - Translate in vivo protein biomarkers } \\
\text { to human health effects } \\
\text { - Continue generation of recombinant } \\
\text { antibodies for protein array development }\end{array}$ \\
\hline
\end{tabular}


tocyte cultures. Comparison of the results with rat liver tissue revealed a good in vivo-in vitro correlation for several protein biomarkers related to oxidative stress and mitochondrial metabolism-regulation (Kikkawa et al., 2005, 2006). Thus, in vitro proteomics has proven to be a valuable approach to identify protein biomarkers for mechanisms of toxicity (e.g., oxidative stress, cell death, or energy metabolism). More effort is now required to translate biomarkers into the in vivo or human situation, when possible using animal tissues or human clinical samples (Gao et al., 2009).

\subsection{Metabolomics}

Metabolomics aims to measure the dynamic response of biological systems by the characterization and quantification of low molecular weight metabolites at a given time point (Tab. 9) (Nicholson and Lindon, 2008). Because the metabolome is defined by gene, transcript, and protein changes, metabolomics is considered to be the omics science closest to the phenotype. Metabolites such as amino acids, oligopeptides, sugars, fatty acids, and other intermediates of biochemical pathways can provide information on the dynamic responses to genetic, physical, pathological, or developmental influences. The number of metabolites in a biological system is estimated to be a few thousand, which is relatively few compared to the number of genes and proteins. Metabolomics, therefore, is considered a more approachable methodology than genomics or proteomics, particularly in translating results to phenotypic changes. Because metabolic changes represent the final outcome of all physiological processes, metabolomics is a relevant approach to study toxicity (Robertson, 2005).

\subsubsection{Metabolomics technologies}

The principal technologies for metabolomics studies are nuclear magnetic resonance spectroscopy (NMR) and mass spectrometry (MS). NMR examines the proton spectrum of a sample, which represents a robust and quantitative measurement. Advantages of NMR are that it is non-invasive, requires no metabolite extraction procedure, and allows a relatively easy structural identification of metabolites. However, limitations of NMR include its relatively low sensitivity compared to MS and the limited number of prevalent metabolites that can be detected. MS-based applications have increased over the last years, mostly due to the high sensitivity, specificity, and ability to detect and identify large numbers of metabolites (Dettmer et al., 2007).

Because the metabolome is dynamic, a quenching procedure is usually applied (e.g., addition of methanol or snap-freezing) to stop cellular metabolism and enzyme activity. Next, an extraction procedure is performed to isolate the metabolites of interest from the biological sample. For MS-based approaches, metabolites are usually fractionated by chromatography (e.g., polar versus non-polar metabolites) before detection. The fractions allow a more effective detection of metabolites with different properties and provide additional information for their identification. The accurate masses obtained can be used to assign empirical formulae to the peaks in the spectra. For high molecular weight metabolites, however, there is an increased probability for isomers. To confirm the identities of metabolites, their accurate mass, retention time parameters, or NMR spectra can be compared to a database with annotated metabolites. Several commercial and public databases are available, such as the Human Metabolome Project (Wishart, 2007) or the METLIN database (Smith et al., 2005), that contain thousands

Tab. 9: Metabolomics

\begin{tabular}{|c|c|c|}
\hline Advantages & Limitations & Developmental needs \\
\hline $\begin{array}{l}\text { - Allows the simultaneous measurement } \\
\text { of hundreds of metabolites } \\
\text { - The omics science considered to be } \\
\text { the closest to the phenotype } \\
\text { - NMR analysis is robust, non-invasive, } \\
\text { quantitative and allows structural } \\
\text { identification of metabolites } \\
\text { - MS analysis is sensitive, quantitative } \\
\text { and detects a high number of } \\
\text { metabolites } \\
\text { - Availability of public and commercial } \\
\text { databases with annotated metabolites } \\
\text { - Both in vitro cell cultures and in vivo } \\
\text { tissue and non-invasive blood, urine } \\
\text { applications } \\
\text { - Shown to predict in vivo liver and } \\
\text { kidney toxicity }\end{array}$ & $\begin{array}{l}\text { - Low sensitivity of NMR } \\
\text { - Limitations for metabolite identification } \\
\text { using MS-based approaches } \\
\text { - In vivo approaches are influenced by } \\
\text { variability factors, e.g. age, gender, } \\
\text { diet, stress, housing conditions, health } \\
\text { status } \\
\text { - In vitro approaches are influenced } \\
\text { by variability factors, e.g. cell culture } \\
\text { conditions, metabolic competence, } \\
\text { media formulations, serum additions, } \\
\text { treatment vehicle } \\
\text { - Quenching and metabolite extraction } \\
\text { procedures limit the detection of } \\
\text { metabolites } \\
\text { - Requires costly NMR or MS technologies } \\
\text { - Complexity of the data analysis and } \\
\text { interpretation, e.g. metabolic pathways }\end{array}$ & $\begin{array}{l}\text { - Explore in vitro approaches for pathway } \\
\text { identification to support "the vision" } \\
\text { - Improve and validate quenching and } \\
\text { extraction procedures for optimized } \\
\text { detections } \\
\text { - Standardize methods to allow data } \\
\text { exchange and comparison } \\
\text { - Develop guidelines to reduce external } \\
\text { variability factors } \\
\text { - Develop improved data analysis and } \\
\text { interpretation methods } \\
\text { - Extend the annotation of metabolomics } \\
\text { data in public databases } \\
\text { - Integrate data into a systems biology } \\
\text { approach } \\
\text { - Translate in vivo and in vitro biomarkers } \\
\text { into clinical utility }\end{array}$ \\
\hline
\end{tabular}


of metabolites. Identities of metabolites not annotated in a database can be confirmed by MS-MS fragmentation. Still, a limitation of the MS-based approach is that often not all metabolites can be identified. The data analysis procedures of NMR and MS datasets depend upon the metabolomics study performed (Cuperlovic-Culf et al., 2010). A profiling study is a hypothesis-driven approach based on pre-selected metabolites relevant for a specific pathway, disease, or toxic perturbation. The metabolites of interest are detected and their concentrations accurately quantified. The metabolite concentrations can be used to identify biomarkers, metabolic pathways, or to develop systems biology models (Lanza et al., 2010). A fingerprinting study is a hypothesis-generating approach based on a complete mass spectrum or a specific mass range of interest. A statistical data analysis compares the different spectra to find significant differences in metabolite patterns and intensities. Principal component analysis (PCA) is a commonly used method to view the variation within multivariate datasets. Based on the most variable components, samples are displayed in a multidimensional plot to reveal clustering patterns that show differences or similarities between samples. Identification of the metabolites responsible for the clustering can provide metabolic fingerprints useful in classifying compounds into toxicity classes or act as biomarkers of toxicity. The limitation of such an unsupervised data analysis is that it can lead to errors due to the inclusion of irrelevant sources of variance. It is therefore important to develop a reproducible method and perform data normalization procedures. The latest software packages control the complete metabolomics process, including data detection, normalization, statistical analysis, metabolite identification, database search, and pathway identification.

\subsubsection{Metabolomics approaches for toxicity testing}

Metabolomics toxicity studies have been performed both in vivo and in vitro. In vivo studies are based on non-invasive urine or blood samples from treated rats or mice, which contain relevant metabolites. Metabolic profiling of blood plasma samples was shown to distinguish different modes of action of compounds based on changes in metabolite patterns. By establishing a database, the modes of action of unknown compounds can be screened in a non-invasive and more cost-efficient manner (van Ravenzwaay et al., 2007). The largest effort to study in vivo toxicity was made by the COMET consortium (Lindon et al., 2005), which has successfully established a database with NMR profiles (urine and blood samples) that allows the prediction of liver and kidney toxicity (Ebbels et al., 2007). A follow-up project, COMET-2, is currently investigating biochemical mechanisms of toxicity and inter-subject variation of kidney and liver toxicity (Nicholson and Lindon, 2008). The prediction of toxicity based on non-invasive urine and blood samples is a promising achievement, since multiple sampling over a long time period allows the monitoring of chronic toxicity. Moreover, the sensitivity of metabolomic analysis allows the performance of low-dose in vivo toxicity studies, as for example carried out for phthalate (Sumner et al., 2009). Such low dose studies refine animal experiments and better represent the real life situation in which humans are exposed to low levels of environmental agents during their lifespan. This is in contrast to the current high-dose animal tests used for human risk assessment.

In vitro toxicity studies using metabolomics have been rather limited so far (Cuperlovic-Culf et al., 2010). However, in vitro applications are likely to increase due to some advantages over the analysis of body fluids. Blood and urine contain a restricted number of metabolites present in organs or tissues (due to the blood-brain barrier, for one example). Moreover, metabolites are diluted in blood and urine volumes, which can limit the detection of less abundant metabolites. Although the in vitro environment is a simplistic model of the in vivo, it sometimes provides a more isolated, controlled, and less variable system. It is known that the results of animal studies are influenced by confounding factors such as diet, age, gender, health status, and stress. A recent study demonstrated the influence of strain and gender on the metabolome profiles of rat blood plasma from a repeated dose study (Strauss et al., 2009). There are, however, a number of challenges for in vitro metabolomics studies. Cellular metabolism depends upon various factors such as growth conditions, age, and differentiation status. Moreover, variations in culture media formulations and additives (e.g., serum) can induce variability. In vitro metabolomics studies can focus on metabolic fingerprinting (intracellular metabolites) or metabolic footprinting (excreted metabolites), but for complete analysis both approaches should be combined. For example, a LC-MS based fingerprinting approach was used to study neurotoxicity in a rat primary neuronal cell model (van Vliet et al., 2008). Furthermore, a LC-MS based footprinting approach was used to investigate valproate toxicity in human embryonic stem cells (Cezar et al., 2007). Using the same footprinting approach, several teratogens were tested in human embryonic stem cells to identify biomarkers for developmental toxicity and generate a preliminary prediction model (West et al., 2010). Metabolomics applications in cell cultures have been initiated only recently, and much is expected from this approach, especially applications in human stem cells - promising because they could provide insight into human toxicity pathways.

\subsection{The potential role of omics technologies in the vision}

Omics technologies will play a key role in establishing the proposed toxicity pathway-based risks assessment. In particular, the comprehensiveness and sensitivity of omics technologies provide excellent opportunities to identify perturbations leading to toxicity. Sensitive technologies can detect small perturbations at relatively low doses and early time points. Moreover, their quantification allows the establishment of robust dose-response models useful to predict no-effect-level concentrations of chemicals and perform adequate risk assessments. Omics approaches have successfully identified biomarkers for toxicity predictions, often before clinical signs of toxicity or disease. The current challenge is to translate and 
validate biomarkers for human toxicity. A problem for this is access to human data, preferably from human clinical trials. Further challenges include the integration and standardization of omics approaches. The integration of omics data should give insight into the interactions between the different cellular components and the cellular pathways that maintain homeostasis in the biological system. Standardization is necessary for the exchange, comparison, or integration of omics data from different experiments or institutions. Moreover, it should guarantee international quality standards for omics data.

\section{The systems biology approach}

For many years, toxicologists have applied the reductionist approach by analyzing individual components of biological systems in response to a toxic exposure. Such studies only show a partial component of the dynamic processes that take place in a biological system. With strong support of the omics sciences and computational modeling approaches, researchers have started to study the complex relationships between different components (genome, proteome, metabolome), thereby creating a systems biology approach (Tab. 10) (Ideker et al., 2001; Waters and Fostel, 2004). Systems biology, one of the newly emerging fields in the life sciences, aims to integrate data from different approaches (e.g., genomics, proteomics, metabolomics, and imaging) to identify and understand molecular and biochemical pathways that control homeostasis (Heijne et al., 2005). It is important to state that identifying all the different genes, proteins, and metabolites in a biological system does not lead to a systems biology understanding (Aderem, 2005). The challenge is to discover the dynamic interactions between the components and how they maintain and control homeostasis. To obtain a system-level understanding of a biological system a number of different properties need to be investigated (Kitano, 2002). The first step is to identify the structural components of the system, including its networks of genes, proteins, and biochemical pathways. In particular, omics technologies combined with molecular techniques such as gene knock-out and silencing techniques are suitable for identifying the interactions and relationships between individual components. Next, the system dynamics need to be understood through the quantitative measurement of the single components at normal homeostasis conditions and after inducing specific perturbations. The perturbations can give insight into the adaptive capacity of the biological system. If the perturbations are too strong for the system to adapt, it will lead to system alterations and a disruption of homeostasis. To understand the dynamics in a biological system it is important not only to have quantitative information but also to understand the temporal and spatial dynamics of molecular and biochemical processes. Such information could be generated using molecular imaging techniques. To create a systems biology level understanding, the structural and dynamic information need to be integrated. The field of bioinformatics has developed visualization programs that formulate detailed graphical and mathematical models of the comprehensive data sets to achieve this. The models can generate hypotheses of the system's behavior in response to a specific perturbation, e.g., a chemical exposure. The current bottleneck for the field of systems biology is not the generation of data but the availability of adequate bioinformatics tools to integrate the information. Another requirement is the development of data standardization and quality assurance guidelines to allow international studies. Systems biology is a fundamental part of the vision since it aims to provide a systems level understanding of toxicity pathways. Currently, it is important to perform a number of small scale, proof-of-principle systems biology studies to confirm if they are able to identify toxicity pathways.

\section{Testing strategies}

Although testing strategies are not explicitly proposed in the vision, they will play a role in keeping the newly envisioned tox-

\section{Tab. 10: The systems biology approach}

\begin{tabular}{|c|c|c|}
\hline Advantages & Limitations & Developmental needs \\
\hline $\begin{array}{l}\text { - Creates a global systemic overview of } \\
\text { processes in a biological system } \\
\text { - Provides understanding of molecular } \\
\text { and biochemical processes related to } \\
\text { toxicity or disease } \\
\text { - Integration of different technologies } \\
\text { (omics, imaging, computational } \\
\text { modeling) } \\
\text { - Aims to identify pathways of toxicity as } \\
\text { proposed in "the vision" }\end{array}$ & $\begin{array}{l}\text { - Limitations in storing, handling, and } \\
\text { analyzing large datasets generated } \\
\text { by different technologies } \\
\text { - Complexity of data analysis and } \\
\text { integration } \\
\text { - Data of different sources increase } \\
\text { variability } \\
\text { - Results are highly dependent on the } \\
\text { quality of the integrated data } \\
\text { - Data will contain unidentified proteins } \\
\text { and metabolites } \\
\text { - The number of existing pathways is } \\
\text { unclear }\end{array}$ & $\begin{array}{l}\text { - Need for novel data normalization, } \\
\text { analysis and interpretation methods } \\
\text { - Provide data in public databases to } \\
\text { facilitate the development of systems } \\
\text { biology } \\
\text { - Provide methods to validate results of } \\
\text { the systems biology approach towards } \\
\text { the human situation } \\
\text { - Need for more interdisciplinary } \\
\text { collaborations }\end{array}$ \\
\hline
\end{tabular}


icity testing approach feasible (Tab. 11). The design of testing strategies aims to make use of both existing and newly generated information to increase the quality of human safety assessment and reduce costs, time, and animal use. Although strategies differ significantly depending on the toxicological hazard assessed, there are a number of common characteristics (Jaworska et al., 2010). Testing strategies are usually based on a tiered testing approach with interim decision points between successive tiers. This differs from a testing battery, in which all compounds are simultaneously tested in a number of selected tests. At each decision point, the interim results are evaluated to decide whether there is sufficient information about a chemical or if additional testing is required for adequate risk assessment. In general, the most time- and cost-efficient methodologies are applied first, followed by the more laborious and costly ones. A testing strategy commonly starts with the gathering and evaluation of existing information (toxicity and human exposure data) from various sources to identify compounds for which adequate information already exists. If existing information is insufficient, the testing strategy is often continued with computational methods, since they are relatively inexpensive compared to laboratory experiments and can provide useful information for first-level decisions. In particular, (quantitative) structure-activity relationship or (Q)SAR analysis, which predicts toxicological properties of a compound based on its chemical structure, can be valuable for testing strategies (Cronin et al., 2003; Hartung and Hoffmann, 2009). Although, QSAR analysis alone is generally not enough for risk assessment, it can be used to categorize compounds into different toxicity classes and thereby identify the most appropriate tests to continue the testing strategy (Russom et al., 2003; Walker and Carlsen, 2002). Moreover, QSAR data can be used to prioritize compounds that pose the greatest risk of adversely affecting human health. The successive tier in a testing strategy can be the generation of new data using either a single test or a battery of in vitro assays. For large in vitro test batteries, high throughput screening technologies are useful. The last resort of integrated testing strategies is often the use of targeted animal experiments; the number of compounds that require testing, however, should be greatly reduced by the information collected

Tab. 11: Integrated testing strategies and generated in the previous tiers. Besides their development, the validation of testing strategies represents a major challenge, since current validation principles are designed for single test methods (Kinsner-Ovaskainen et al., 2009).

\section{Concluding remarks}

The publication of the vision has had a major impact on the field of toxicology. This is reflected, in part, by the publication of related scientific articles, the organization of related meetings and workshops, and the formation of agency alliances aiming for its implementation (Collins et al., 2008). Moreover, it has provoked a global discussion among various stakeholders who have different interpretations and views regarding its feasibility and practical implementation. Current challenges for the vision include the implementation and integration of the proposed technologies into an adequate new paradigm and demonstration of its predictive capacity for human toxicity in comparison to current animal-based testing. Proof-of-principle studies are required to identify the first human toxicity pathways and predict relevant human blood or tissue concentrations from in vitro concentrations triggering toxicity pathways (for example, in human cells). For the latter, adequate PBPK models need to be developed which take into account chemical characteristics and human pharmacokinetic parameters such as absorption, distribution, metabolism, and excretion (Forsby and Blaauboer, 2007; Bouvier d'Yvoire et al., 2007). Such studies will demonstrate the feasibility of the vision and create more confidence. Once the toxicity pathway-based risk assessment approach is established, larger studies can be set up to identify all existing human toxicity pathways. Several studies are ongoing at the EPA and the National Institute of Health Chemical Genomics Center, which apply high throughput and omics technologies to identify toxicity pathways and investigate their ability to predict human toxicity (Schmidt, 2009). It seems that toxicology has started to give up on traditional animal-based testing and is moving towards the implementation of new technologies expected to provide a more accurate, science-driven, and humane assessment of human toxicological risk.

\begin{tabular}{|c|c|c|}
\hline Advantages & Limitations & Developmental needs \\
\hline $\begin{array}{l}\text { - More time and cost efficient compared } \\
\text { to testing large batteries } \\
\text { - Decision points between tiered tests } \\
\text { allows the removal of chemicals with } \\
\text { sufficient information } \\
\text { - Reduces the risk of false positives } \\
\text { - Potential to reduce time, costs and } \\
\text { animal numbers for toxicity testing }\end{array}$ & $\begin{array}{l}\text { - Design of testing strategies is complex } \\
\text { - Limited experience applying testing } \\
\text { strategies } \\
\text { - Limited number of tests that can be } \\
\text { included to maintain feasibility } \\
\text { - Unclear validation process } \\
\text { - High costs and work required for a } \\
\text { prospective validation }\end{array}$ & $\begin{array}{l}\text { - Investigate the optimal design of } \\
\text { integrated testing strategies } \\
\text { - Perform proof-of-principle studies } \\
\text { using some initial (relatively simple) } \\
\text { strategies } \\
\text { - Explore prospective validation } \\
\text { principles } \\
\text { - Perform retrospective validation } \\
\text { studies using existing data } \\
\text { - Involve regulators to apply and } \\
\text { support the future approval of testing } \\
\text { strategies }\end{array}$ \\
\hline
\end{tabular}




\section{References}

Aardema, M. J. and MacGregor, J. T. (2002). Toxicology and genetic toxicology in the new era of "toxicogenomics": impact of "-omics" technologies. Mutat. Res. 499, 13-25.

Abraham, V. C., Towne, D. L., Waring, J. F. et al. (2008). Application of a high-content multiparameter cytotoxicity assay to prioritize compounds based on toxicity potential in humans. J. Biomol. Screen 13, 527-537.

Aderem, A. (2005). Systems biology: its practice and challenges. Cell 121, 511-513.

Agarwal, S., Holton, K. L. and Lanza, R. (2008). Efficient differentiation of functional hepatocytes from human embryonic stem cells. Stem Cells 26, 1117-1127.

Alepee, N., Tornier, C., Robert, C. et al . (2010). A catch-up validation study on reconstructed human epidermis (SkinEthic RHE) for full replacement of the Draize skin irritation test. Toxicol. In Vitro 24, 257-266.

Andersen, M. E. and Krewski, D. (2009). Toxicity testing in the $21^{\text {st }}$ century: bringing the vision to life. Toxicol. Sci. 107, 324-330.

Anderson, G. L., Cole, R. D. and Williams, P. L. (2004). Assessing behavioral toxicity with Caenorhabditis elegans. Environ. Toxicol. Chem. 23, 1235-1240.

Aschner, M. and Kimelberg, H. K. (1991). The use of astrocytes in culture as model systems for evaluating neurotoxicinduced-injury. Neurotoxicology 12, 505-517.

Asha, S. and Vidyavathi, M. (2010). Role of human liver microsomes in in vitro metabolism of drugs-a review. Appl. Biochem. Biotechnol. 160, 1699-1722.

Astin, J. W., O'Neil, N. J. and Kuwabara, P. E. (2008). Nucleotide excision repair and the degradation of RNA pol II by the Caenorhabditis elegans XPA and Rsp5 orthologues, RAD-3 and WWP-1. DNA Repair (Amst.) 7, 267-280.

Baer, P. C., Bereiter-Hahn, J., Schubert, R. et al. (2006). Differentiation status of human renal proximal and distal tubular epithelial cells in vitro: Differential expression of characteristic markers. Cells Tissues Organs 184, 16-22.

Baharvand, H., Hashemi, S. M. and Shahsavani, M. (2008). Differentiation of human embryonic stem cells into functional hepatocyte-like cells in a serum-free adherent culture condition. Differentiation 76, 465-477.

Bakand, S., Winder, C., Khalil, C. et al. (2005). Toxicity assessment of industrial chemicals and airborne contaminants: transition from in vivo to in vitro test methods: a review. Inhal. Toxicol. 17, 775-787.

Balls, M. (1998). Mechanistic approaches and the development of alternative toxicity test methods. Environ. Health Perspect. 106, Suppl. 2, 453-457.

Basma, H., Soto-Gutierrez, A., Yannam, G. R. et al. (2009). Differentiation and transplantation of human embryonic stem cell-derived hepatocytes. Gastroenterology 136, 990-999.

Bilen, J. and Bonini, N. M. (2005). Drosophila as a model for human neurodegenerative disease. Annu. Rev. Genet. 39, 153171.

Bird, S. D., Doevendans, P. A., van Rooijen, M. A. et al. (2003). The human adult cardiomyocyte phenotype. Cardiovasc. Res.
58, 423-434.

Bistola, V., Nikolopoulou, M., Derventzi, A. et al. (2008). Longterm primary cultures of human adult atrial cardiac myocytes: cell viability, structural properties and BNP secretion in vitro. Int. J. Cardiol. 131, 113-122.

Blackstock, W. P. and Weir, M. P. (1999). Proteomics: quantitative and physical mapping of cellular proteins. Trends Biotechnol. 17, 121-127.

Bongso, A., Fong, C. Y., Ng, S. C. et al. (1994). Isolation and culture of inner cell mass cells from human blastocysts. Hum. Reprod. 9, 2110-2117.

Bottini, A. A. and Hartung, T. (2009). Food for thought ... on the economics of animal testing. ALTEX 26, 3-16.

Bouvier d'Yvoire, M., Prieto, P., Blaauboer, B. J. et al. (2007). Physiologically-based Kinetic Modelling (PBK Modelling): meeting the 3Rs agenda. The report and recommendations of ECVAM Workshop 63. ATLA 35, 661-671.

Boyd, W. A., McBride, S. J. and Freedman, J. H. (2007). Effects of genetic mutations and chemical exposures on Caenorhabditis elegans feeding: evaluation of a novel, high-throughput screening assay. PLoS One 2, e1259.

Bozina, N., Bradamante, V. and Lovric, M. (2009). Genetic polymorphism of metabolic enzymes P450 (CYP) as a susceptibility factor for drug response, toxicity, and cancer risk. Arh. Hig. Rada Toksikol. 60, 217-242.

Braam, S. R., Tertoolen, L., van de Stolpe, A. et al. (2010). Prediction of drug-induced cardiotoxicity using human embryonic stem cell-derived cardiomyocytes. Stem Cell Res. 4, 107-116.

Bracken, M. B. (2009). Why animal studies are often poor predictors of human reactions to exposure. J. R. Soc. Med. 102, 120-122.

Breier, J. M., Gassmann, K., Kayser, R. et al. (2010). Neural progenitor cells as models for high-throughput screens of developmental neurotoxicity: state of the science. Neurotoxicol. Teratol. 32, 4-15.

Brolen, G., Sivertsson, L., Bjorquist, P. et al. (2010). Hepatocyte-like cells derived from human embryonic stem cells specifically via definitive endoderm and a progenitor stage. $J$. Biotechnol. 145, 284-294.

Brophy, C. M., Luebke-Wheeler, J. L., Amiot, B. P. et al . (2009). Rat hepatocyte spheroids formed by rocked technique maintain differentiated hepatocyte gene expression and function. Hepatology 49, 578-586.

Brown, C. D., Sayer, R., Windass, A. S. et al. (2008). Characterisation of human tubular cell monolayers as a model of proximal tubular xenobiotic handling. Toxicol. Appl. Pharmacol. 233, 428-438.

Bucher, J. R. (2002). The National Toxicology Program rodent bioassay: designs, interpretations, and scientific contributions. Ann. N. Y. Acad. Sci. 982, 198-207.

Buesen, R., Genschow, E., Slawik, B. et al. (2009). Embryonic stem cell test remastered: comparison between the validated EST and the new molecular FACS-EST for assessing developmental toxicity in vitro. Toxicol. Sci. 108, 389-400.

Burns, C. G., Milan, D. J., Grande, E. J. et al. (2005). Highthroughput assay for small molecules that modulate zebrafish 
embryonic heart rate. Nat. Chem. Biol. 1, 263-264.

Bus, J. S. and Becker, R. A. (2009). Toxicity testing in the $21^{\text {st }}$ century: a view from the chemical industry. Toxicol. Sci. 112, 297-302.

Butcher, E. C., Berg, E. L. and Kunkel, E. J. (2004). Systems biology in drug discovery. Nat. Biotechnol. 22, 1253-1259.

Buzanska, L., Sypecka, J., Nerini-Molteni, S. et al. (2009). A human stem cell-based model for identifying adverse effects of organic and inorganic chemicals on the developing nervous system. Stem Cells 27, 2591-2601.

Cali, J. J., Niles, A., Valley, M. P. et al. (2008). Bioluminescent assays for ADMET. Expert Opin. Drug Metab. Toxicol. 4, 103-120.

Camano, S., Lazaro, A., Moreno-Gordaliza, E. et al. (2010). Cilastatin attenuates cisplatin-induced proximal tubular cell damage. J. Pharmacol. Exp. Ther. 334, 419-429.

Cannon, C. L., Neal, P. J., Southee, J. A. et al. (1994). New epidermal model for dermal irritancy testing. Toxicol. In Vitro 8, 889-891.

Carere, A., Stammati, A. and Zucco, F. (2002). In vitro toxicology methods: impact on regulation from technical and scientific advancements. Toxicol. Lett. 127, 153-160.

Carlson, T. J. and Fisher, M. B. (2008). Recent advances in high throughput screening for ADME properties. Comb. Chem. High Throughput Screen. 11, 258-264.

Carpenter,A. E. and Sabatini, D. M. (2004). Systematic genomewide screens of gene function. Nat. Rev. Genet. 5, 11-22.

Caspi, O., Itzhaki, I., Kehat, I. et al. (2009). In vitro electrophysiological drug testing using human embryonic stem cell derived cardiomyocytes. Stem Cells Dev. 18, 161-172.

Cezar, G. G., Quam, J. A., Smith, A. M. et al. (2007). Identification of small molecules from human embryonic stem cells using metabolomics. Stem Cells Dev. 16, 869-882.

Chaerkady, R., Kerr, C. L., Marimuthu, A. et al. (2009). Temporal analysis of neural differentiation using quantitative proteomics. J. Proteome Res. 8, 1315-1326.

Chalfie, M., Tu, Y., Euskirchen, G. et al. (1994). Green fluorescent protein as a marker for gene expression. Science 263, 802-805.

Chan, P. K., Lin, C. C. and Cheng, S. H. (2009). Noninvasive technique for measurement of heartbeat regularity in zebrafish (Danio rerio) embryos. BMC Biotechnol. 9, 11.

Chapin, R. E. and Stedman, D. B. (2009). Endless possibilities: stem cells and the vision for toxicology testing in the $21^{\text {st }}$ century. Toxicol. Sci. 112, 17-22.

Charbit, B., Alvarez, J. C., Dasque, E. et al. (2008). Droperidol and ondansetron-induced QT interval prolongation: a clinical drug interaction study. Anesthesiology 109, 206-212.

Chin, M. H., Mason, M. J., Xie, W. et al. (2009). Induced pluripotent stem cells and embryonic stem cells are distinguished by gene expression signatures. Cell Stem Cell 5, 111-123.

Chivu, M., Dima, S. O., Stancu, C. I. et al. (2009). In vitro hepatic differentiation of human bone marrow mesenchymal stem cells under differential exposure to liver-specific factors. Transl. Res. 154, 122-132.
Cho, S. Y., Lee, E. Y., Kim, H. Y. et al. (2008). Protein profiling of human plasma samples by two-dimensional electrophoresis. Methods Mol. Biol. 428, 57-75.

Choi, K. D., Yu, J., Smuga-Otto, K. et al. (2009). Hematopoietic and endothelial differentiation of human induced pluripotent stem cells. Stem Cells 27, 559-567.

Chung, S., Sonntag, K. C., Andersson, T. et al. (2002). Genetic engineering of mouse embryonic stem cells by Nurr1 enhances differentiation and maturation into dopaminergic neurons. Eur. J. Neurosci. 16, 1829-1838.

Clarke, D. L., Johansson, C. B., Wilbertz, J. et al. (2000). Generalized potential of adult neural stem cells. Science 288 , 1660-1663.

Coecke, S., Ahr, H., Blaauboer, B. J. et al. (2006). Metabolism: a bottleneck in in vitro toxicological test development. The report and recommendations of ECVAM workshop 54. ATLA $34,49-84$.

Coecke, S., Goldberg, A. M., Allen, S. et al. (2007). Workgroup report: incorporating in vitro alternative methods for developmental neurotoxicity into international hazard and risk assessment strategies. Environ. Health Perspect. 115, 924-931.

Cole, R. D., Anderson, G. L. and Williams, P. L. (2004). The nematode Caenorhabditis elegans as a model of organophosphate-induced mammalian neurotoxicity. Toxicol. Appl. Pharmacol. 194, 248-256.

Collins, F. S., Morgan, M. and Patrinos, A. (2003). The Human Genome Project: lessons from large-scale biology. Science 300, 286-290.

Collins, F. S., Gray, G. M. and Bucher, J. R. (2008). Toxicology. Transforming environmental health protection. Science 319 , 906-907.

Creton, R. (2009). Automated analysis of behavior in zebrafish larvae. Behav. Brain Res. 203, 127-136.

Cronin, M. T., Jaworska, J. S., Walker, J. D. et al. (2003). Use of QSARs in international decision-making frameworks to predict health effects of chemical substances. Environ. Health Perspect. 111, 1391-1401.

Cronin, C. J., Feng, Z. and Schafer, W. R. (2006). Automated imaging of C. elegans behavior. Methods Mol. Biol.351, 241251.

Cubeddu, L. X. (2003). QT prolongation and fatal arrhythmias: a review of clinical implications and effects of drugs. Am. J. Ther. 10, 452-457.

Cuperlovic-Culf, M., Barnett, D. A., Culf, A. S. et al. (2010). Cell culture metabolomics: applications and future directions. Drug Discov. Today 15, 610-621.

Curren, R. D., Mun, G. C., Gibson, D. P. et al. (2006). Development of a method for assessing micronucleus induction in a 3D human skin model (EpiDerm). Mutat. Res. 607, 192-204.

Dash, A., Inman, W., Hoffmaster, K. et al. (2009). Liver tissue engineering in the evaluation of drug safety. Expert Opin. Drug Metab. Toxicol. 5, 1159-1174.

Dettmer, K., Aronov, P. A. and Hammock, B. D. (2007). Mass spectrometry-based metabolomics. Mass Spectrom. Rev. 26, 51-78. 
Dhawan, R., Dusenbery, D. B. and Williams, P. L. (1999). Comparison of lethality, reproduction, and behavior as toxicological endpoints in the nematode Caenorhabditis elegans. $J$. Toxicol. Environ. Health A 58, 451-462.

Diaz, D., Scott, A., Carmichael, P. et al. (2007). Evaluation of an automated in vitro micronucleus assay in CHO-K1 cells. Mutat. Res. 630, 1-13.

Dix, D. J., Houck, K. A., Martin, M. T. et al. (2007). The ToxCast program for prioritizing toxicity testing of environmental chemicals. Toxicol. Sci. 95, 5-12.

Du, W., Wang, Y., Luo, Q. et al. (2006). Optical molecular imaging for systems biology: from molecule to organism. Anal. Bioanal. Chem. 386, 444-457.

Duggan, D. J., Bittner, M., Chen, Y. et al. (1999). Expression profiling using cDNA microarrays. Nat. Genet. 21, 10-14.

Ebbels, T. M., Keun, H. C., Beckonert, O. P. et al. (2007). Prediction and classification of drug toxicity using probabilistic modeling of temporal metabolic data: the consortium on metabonomic toxicology screening approach. J. Proteome Res. 6, 4407-4422.

Eddins, D., Cerutti, D., Williams, P. et al. (2010). Zebrafish provide a sensitive model of persisting neurobehavioral effects of developmental chlorpyrifos exposure: comparison with nicotine and pilocarpine effects and relationship to dopamine deficits. Neurotoxicol. Teratol. 32, 99-108.

Eimon, P. M. and Rubinstein, A. L. (2009). The use of in vivo zebrafish assays in drug toxicity screening. Expert. Opin. Drug Metab. Toxicol. 5, 393-401.

Elbashir, S. M., Harborth, J., Weber, K. et al. (2002). Analysis of gene function in somatic mammalian cells using small interfering RNAs. Methods 26, 199-213.

Eskes, C., Juillerat-Jeanneret, L., Leuba, G. et al. (2003). Involvement of microglia-neuron interactions in the tumor necrosis factor-alpha release, microglial activation, and neurodegeneration induced by trimethyltin. J. Neurosci. Res. 71, 583-590.

European Commission (2006). Regulation (EC) of No 1907/2006 of the European parliament and of the council 18 December 2006 concerning the Registration, Evaluation, Authorisation and Restriction of Chemicals (REACH), establishing a European Chemicals Agency, amending Directive 1999/45/ EC and repealing Council Regulation (EEC) No 793/93 and Commission Regulation (EC) No 1488/94 as well as Council Directive 76/769/EEC and Commission Directives 91/155/ EEC, 93/67/EEC, 93/105/EC and 2000/21/EC.

Evans, G. A. (2000). Designer science and the "omic" revolution. Nat. Biotechnol. 18, 127.

Fan, C. Y., Cowden, J., Simmons, S. O. et al. (2010). Gene expression changes in developing zebrafish as potential markers for rapid developmental neurotoxicity screening. Neurotoxicol. Teratol. 32, 91-98.

Farzaneh, Z., Pournasr, B., Ebrahimi, M. et al. (2010). Enhanced functions of human embryonic stem cell-derived hepatocytelike cells on three-dimensional nanofibrillar surfaces. Stem Cell Rev. 6, 601-610.
Fentem, J. H., Archer, G. E., Balls, M. et al. (1998). The ECVAM international validation study on in vitro tests for skin corrosivity. 2. results and evaluation by the management team. Toxicol. In Vitro 12, 483-524.

Fernandes, K. J., McKenzie, I. A., Mill, P. et al. (2004). A dermal niche for multipotent adult skin-derived precursor cells. Nat. Cell Biol. 6, 1082-1093.

Fernandes, T. G., Diogo, M. M., Clark, D. S. et al. (2009). High-throughput cellular microarray platforms: applications in drug discovery, toxicology and stem cell research. Trends Biotechnol. 27, 342-349.

Fernandez-Suarez, M. and Ting, A. Y. (2008). Fluorescent probes for super-resolution imaging in living cells. Nat. Rev. Mol. Cell Biol. 9, 929-943.

Ferrer-Dufol, A. and Menao-Guillen, S. (2009). Toxicogenomics and clinical toxicology: an example of the connection between basic and applied sciences. Toxicol. Lett. 186, 2-8.

Fletcher, S. T. and Basketter, D. A. (2006). Proteomic analysis of the response of EpiDerm cultures to sodium lauryl sulphate. Toxicol. In Vitro 20,975-985.

Forsby, A. and Blaauboer, B. (2007). Integration of in vitro neurotoxicity data with biokinetic modelling for the estimation of in vivo neurotoxicity. Hum. Exp. Toxicol. 26, 333-338.

Forsby, A., Bal-Price, A. K., Camins, A. et al. (2009). Neuronal in vitro models for the estimation of acute systemic toxicity. Toxicol. In Vitro 23, 1564-1569.

Frangioni, J. V. (2003). In vivo near-infrared fluorescence imaging. Curr. Opin. Chem. Biol. 7, 626-634.

Gao, Y., Holland, R. D. and Yu, L. R. (2009). Quantitative proteomics for drug toxicity. Brief Funct. Genomic Proteomic 8, 158-166.

Garbis, S., Lubec, G. and Fountoulakis, M. (2005). Limitations of current proteomics technologies. J. Chromatogr. A 1077, 1-18.

Garte, S., Taioli, E., Popov, T. et al. (2008). Genetic susceptibility to benzene toxicity in humans. J. Toxicol. Environ. Health A 71, 1482-1489.

Gatzidou, E. T., Zira, A. N. and Theocharis, S. E. (2007). Toxicogenomics: a pivotal piece in the puzzle of toxicological research. J. Appl. Toxicol. 27, 302-309.

Gaudio, E., Carpino, G., Cardinale, V. et al. (2009). New insights into liver stem cells. Dig. Liver Dis. 41, 455-462.

Genschow, E., Scholz, G., Brown, N. et al. (2000). Development of prediction models for three in vitro embryotoxicity tests in an ECVAM validation study. In Vitr. Mol. Toxicol. 13, 51-66.

Genschow, E., Spielmann, H., Scholz, G. et al. (2004). Validation of the embryonic stem cell test in the international ECVAM validation study on three in vitro embryotoxicity tests. ATLA 32, 209-244.

George, J., Singh, R., Mahmood, Z. et al. (2010). Toxicoproteomics: new paradigms in toxicology research. Toxicol. Mech. Methods 20, 415-423.

Gheysens, O. and Mottaghy, F. M. (2009). Method of bioluminescence imaging for molecular imaging of physiological and pathological processes. Methods 48, 139-145. 
Giles, A. C. and Rankin, C. H. (2009). Behavioral and genetic characterization of habituation using Caenorhabditis elegans. Neurobiol. Learn Mem. 92, 139-146.

Giordano, G., Kavanagh, T. J. and Costa, L. G. (2009). Mouse cerebellar astrocytes protect cerebellar granule neurons against toxicity of the polybrominated diphenyl ether (PBDE) mixture DE-71. Neurotoxicology 30, 326-329.

Giuliano, K. A., Johnston, P. A., Gough, A. et al. (2006). Systems cell biology based on high-content screening. Methods Enzymol. 414, 601-619.

Goldberg, A.M. (ed.) (1983). Alternative methods in toxicology, product safety evaluation. Vol. 1. New York: Mary Ann Liebert, Inc.

Gottmann, E., Kramer, S., Pfahringer, B. et al. (2001). Data quality in predictive toxicology: reproducibility of rodent carcinogenicity experiments. Environ. Health Perspect. 109, 509-514.

Grandjean, P. and Landrigan, P. J. (2006). Developmental neurotoxicity of industrial chemicals. Lancet 368, 2167-2178.

Greenhough, S., Medine, C. N. and Hay, D. C. (2010). Pluripotent stem cell derived hepatocyte like cells and their potential in toxicity screening. Toxicology 278, 250-255.

Griffith, L. G. and Swartz, M.A. (2006). Capturing complex 3D tissue physiology in vitro. Nat. Rev. Mol. Cell Biol. 7, 211224.

Guguen-Guillouzo, C., Corlu, A. and Guillouzo, A. (2010). Stem cell-derived hepatocytes and their use in toxicology. Toxicology 270, 3-9.

Guillouzo, A. (1998). Liver cell models in in vitro toxicology. Environ. Health Perspect. 106, Suppl. 2, 511-532.

Haase, A., Olmer, R., Schwanke, K. et al. (2009). Generation of induced pluripotent stem cells from human cord blood. Cell Stem Cell 5, 434-441.

Harry, G. J., Billingsley, M., Bruinink, A. et al. (1998). In vitro techniques for the assessment of neurotoxicity. Environ. Health Perspect. 106, Suppl. 1, 131-158.

Harry, G. J. and Tiffany-Castiglioni, E. (2005). Evaluation of neurotoxic potential by use of in vitro systems. Expert Opin. Drug Metab. Toxicol. 1, 701-713.

Hartung, T. (2001). Three Rs potential in the development and quality control of pharmaceuticals. ALTEX 18, Suppl. 1, 3-13.

Hartung, T. (2008). Food for thought ... on animal tests. ALTEX 25, 3-16.

Hartung, T. (2009a). A toxicology for the $21^{\text {st }}$ century - mapping the road ahead. Toxicol. Sci. 109, 18-23.

Hartung, T. (2009b). Toxicology for the twenty-first century. Nature 460, 208-212.

Hartung, T. and Daston, G. (2009). Are in vitro tests suitable for regulatory use? Toxicol. Sci. 111, 233-237.

Hartung, T. and Hoffmann, S. (2009). Food for thought ... on in silico methods in toxicology. ALTEX 26, 155-166.

Hartung, T. (2010). Food for thought ... on alternative methods for chemical safety testing. ALTEX 27, 3-14.

Hashizume, T., Yoshitomi, S., Asahi, S. et al. (2009). In vitro micronucleus test in HepG2 transformants expressing a series of human cytochrome $\mathrm{P} 450$ isoforms with chemicals requiring metabolic activation. Mutat. Res. 677, 1-7.

Hay, D. C., Zhao, D., Fletcher, J. et al. (2008). Efficient differentiation of hepatocytes from human embryonic stem cells exhibiting markers recapitulating liver development in vivo. Stem Cells 26, 894-902.

Heijne, W. H., Kienhuis, A. S., van Ommen, B. et al. (2005). Systems toxicology: applications of toxicogenomics, transcriptomics, proteomics and metabolomics in toxicology. Expert Rev. Proteomics 2, 767-780.

Heinloth, A. N., Irwin, R. D., Boorman, G. A. et al. (2004). Gene expression profiling of rat livers reveals indicators of potential adverse effects. Toxicol. Sci. 80, 193-202.

Helmcke, K. J., Syversen, T., Miller, D. M., 3rd et al. (2009). Characterization of the effects of methylmercury on Caenorhabditis elegans. Toxicol. Appl. Pharmacol. 240, 265-272.

Helmcke, K. J., Avila, D. S. and Aschner, M. (2010). Utility of Caenorhabditis elegans in high throughput neurotoxicological research. Neurotoxicol. Teratol. 32, 62-67.

Hidaka, K., Lee, J. K., Kim, H. S. et al. (2003). Chamber-specific differentiation of $\mathrm{Nkx} 2.5$-positive cardiac precursor cells from murine embryonic stem cells. FASEB J. 17, 740-742.

Hieter, P. and Boguski, M. (1997). Functional genomics: it's all how you read it. Science 278, 601-602.

Hill, A. J., Teraoka, H., Heideman, W. et al. (2005). Zebrafish as a model vertebrate for investigating chemical toxicity. Toxicol. Sci. 86, 6-19.

Hoffmann, S. and Hartung, T. (2005). Diagnosis: toxic! - trying to apply approaches of clinical diagnostics and prevalence in toxicology considerations. Toxicol. Sci. 85, 422-428.

Hogberg, H. T., Kinsner-Ovaskainen, A., Hartung, T. et al. (2009). Gene expression as a sensitive endpoint to evaluate cell differentiation and maturation of the developing central nervous system in primary cultures of rat cerebellar granule cells (CGCs) exposed to pesticides. Toxicol. Appl. Pharmacol. 235, 268-286.

Hogberg, H. T., Kinsner-Ovaskainen, A., Coecke, S. et al. (2010). mRNA expression is a relevant tool to identify developmental neurotoxicants using an in vitro approach. Toxicol. Sci. 113, 95-115.

Honegger, P., Lenoir, D. and Favrod, P. (1979). Growth and differentiation of aggregating fetal brain cells in a serum-free defined medium. Nature 282, 305-308.

Honegger, P. and Schilter, B. (1992). Serum free aggregate cultures of foetal rat brain and liver cells: methodology and some practical applications in neurotoxicology. In G. Zbinden (ed.), The brain and bits and pieces: In vitro techniques in neurobiology, neuropharmacology and neurotoxicology (51-79). Zollikon, Switzerland: MTC Verlag.

Honegger, P. and Monnet-Tschudi, F. (2001). Aggregating neural cell cultures. In S. Fedoroff and A. Richardson (eds.), Protocols for Neural Cell Culture. ( $3^{\text {rd }}$ ed., 199-218). Totowa, N.J.: Humana Press.

Houck, K. A. and Kavlock, R. J. (2008). Understanding mechanisms of toxicity: insights from drug discovery research. Toxicol. Appl. Pharmacol. 227, 163-178. 
Hu, B. Y., Weick, J. P., Yu, J. et al. (2010). Neural differentiation of human induced pluripotent stem cells follows developmental principles but with variable potency. Proc. Natl. Acad.Sci. U S A 107, 4335-4340.

Ideker, T., Galitski, T. and Hood, L. (2001). A new approach to decoding life: systems biology. Annu. Rev. Genomics Hum. Genet. 2, 343-372.

Jadhav, K. B. and Rajini, P. S. (2009). Evaluation of sublethal effects of dichlorvos upon Caenorhabditis elegans based on a set of end points of toxicity. J. Biochem. Mol. Toxicol. 23, 9-17.

James, P. (1997). Protein identification in the post-genome era: the rapid rise of proteomics. Q. Rev. Biophys. 30, 279-331.

Jaworska, J., Gabbert, S. and Aldenberg, T. (2010). Towards optimization of chemical testing under REACH: a Bayesian network approach to Integrated Testing Strategies. Regul. Toxicol. Pharmacol. 57, 157-167.

Jirova, D., Basketter, D., Liebsch, M. et al. (2010). Comparison of human skin irritation patch test data with in vitro skin irritation assays and animal data. Contact Dermatitis 62, 109116.

Judson, R. S., Houck, K. A., Kavlock, R. J. et al. (2010). In vitro screening of environmental chemicals for targeted testing prioritization: the ToxCast project. Environ. Health Perspect. $118,485-492$.

Kaletta, T. and Hengartner, M. O. (2006). Finding function in novel targets: C. elegans as a model organism. Nat. Rev. Drug Discov. 5, 387-398.

Kammili, R. K., Taylor, D. G., Xia, J. et al. (2010). Generation of novel reporter stem cells and their application for molecular imaging of cardiac-differentiated stem cells in vivo. Stem Cells Dev. 19, 1437-1448.

Kandarova, H., Liebsch, M., Schmidt, E. et al. (2006). Assessment of the skin irritation potential of chemicals by using the SkinEthic reconstructed human epidermal model and the common skin irritation protocol evaluated in the ECVAM skin irritation validation study. ATLA 34, 393-406.

Kari, G., Rodeck, U. and Dicker, A. P. (2007). Zebrafish: an emerging model system for human disease and drug discovery. Clin. Pharmacol. Ther. 82, 70-80.

Katagiri, F. and Glazebrook, J. (2009). Overview of mRNA expression profiling using DNA microarrays. Curr. Protoc. Mol. Biol. Chapter 22, Unit 2224.

Kehat, I., Amit, M., Gepstein, A. et al. (2003). Development of cardiomyocytes from human ES cells. Methods Enzymol. $365,461-473$.

Kennedy, S. (2002). The role of proteomics in toxicology: identification of biomarkers of toxicity by protein expression analysis. Biomarkers 7, 269-290.

Kikkawa, R., Yamamoto, T., Fukushima, T. et al. (2005). Investigation of a hepatotoxicity screening system in primary cell cultures - "what biomarkers would need to be addressed to estimate toxicity in conventional and new approaches?". $J$. Toxicol.Sci. 30, 61-72.

Kikkawa, R., Fujikawa, M., Yamamoto, T. et al. (2006). In vivo hepatotoxicity study of rats in comparison with in vitro hepa- totoxicity screening system. J. Toxicol. Sci. 31, 23-34.

Kim, J. H., Auerbach, J. M., Rodriguez-Gomez, J. A. et al. (2002). Dopamine neurons derived from embryonic stem cells function in an animal model of Parkinson's disease. $\mathrm{Na}$ ture 418, 50-56.

Kim, S. and Misra, A. (2007). SNP genotyping: technologies and biomedical applications. Annu. Rev. Biomed.Eng. 9, 289320.

Kinsner-Ovaskainen, A., Akkan, Z., Casati, S. et al. (2009). Overcoming barriers to validation of non-animal partial replacement methods/Integrated Testing Strategies: the report of an EPAA-ECVAM workshop. ATLA 37, 437-444.

Kirchhoff, F., Dringen, R. and Giaume, C. (2001). Pathways of neuron-astrocyte interactions and their possible role in neuroprotection. Eur. Arch. Psychiatry Clin. Neurosci. 251, 159169.

Kitano, H. (2002). Systems biology: a brief overview. Science 295, 1662-1664.

Klohs, J., Wunder, A. and Licha, K. (2008). Near-infrared fluorescent probes for imaging vascular pathophysiology. Basic Res. Cardiol. 103, 144-151.

Knight, A. (2007). Animal experiments scrutinised: systematic reviews demonstrate poor human clinical and toxicological utility. ALTEX 24, 320-325.

Krewski, D., Andersen, M. E., Mantus, E. et al. (2009). Toxicity testing in the $21^{\text {st }}$ century: implications for human health risk assessment. Risk Anal. 29, 474-479.

Kronick, M. N. (2004). Creation of the whole human genome microarray. Expert Rev. Proteomics 1, 19-28.

Kuegler, P. B., Zimmer, B., Waldmann, T. et al. (2010). Markers of murine embryonic and neural stem cells, neurons and astrocytes: reference points for developmental neurotoxicity testing. ALTEX 27, 17-42.

Lagido, C., McLaggan, D., Flett, A. et al. (2009). Rapid sublethal toxicity assessment using bioluminescent Caenorhabditis elegans, a novel whole-animal metabolic biosensor. Toxicol. Sci. 109, 88-95.

Lanza, I. R., Zhang, S., Ward, L. E. et al. (2010). Quantitative metabolomics by H-NMR and LC-MS/MS confirms altered metabolic pathways in diabetes. PLoS One 5, e10538.

Lavon, N. (2010). Generation of hepatocytes from human embryonic stem cells. Methods Mol. Biol. 640, 237-246.

Lee, J., Cuddihy, M. J. and Kotov, N. A. (2008). Three-dimensional cell culture matrices: state of the art. Tissue Eng. Part B Rev. 14, 61-86.

Lee, D. Y. and Li, K. C. (2009). Systems diagnostics: the systems approach to molecular imaging. AJR Am. J. Roentgenol. 193, 287-294.

Lee, C. J., Spalding, A. C., Ben-Josef, E. et al. (2010). In vivo bioluminescent imaging of irradiated orthotopic pancreatic cancer xenografts in nonobese diabetic-severe combined immunodeficient mice: a novel method for targeting and assaying efficacy of ionizing radiation. Transl. Oncol. 3, 153-159.

Leist, M., Bremer, S., Brundin, P. et al. (2008). The biological and ethical basis of the use of human embryonic stem cells for in vitro test systems or cell therapy. ALTEX 25, 163-190. 
Leung, M. C., Williams, P. L., Benedetto, A. et al. (2008). Caenorhabditis elegans: an emerging model in biomedical and environmental toxicology. Toxicol. Sci. 106, 5-28.

Li, W., Lam, M., Choy, D. et al. (2006). Human primary renal cells as a model for toxicity assessment of chemo-therapeutic drugs. Toxicol. In Vitro 20, 669-676.

Li, Y., Kang, X., Guo, K. et al. (2009). Proteome alteration of early-stage differentiation of mouse embryonic stem cells into hepatocyte-like cells. Electrophoresis 30, 1431-1440.

Li, J., Tao, R., Wu, W. et al. (2010). 3D PLGA scaffolds improve differentiation and function of bone marrow mesenchymal stem cell-derived hepatocytes. Stem Cells Dev. 19, 1427-1436.

Lindon, J. C., Keun, H. C., Ebbels, T. M. et al. (2005). The Consortium for Metabonomic Toxicology (COMET): aims, activities and achievements. Pharmacogenomics 6, 691-699.

Liu, A. M., New, D. C., Lo, R. K. et al. (2009). Reporter gene assays. Methods Mol. Biol. 486, 109-123.

Liu, T., Zhang, S., Chen, X. et al. (2010). Hepatic differentiation of mouse embryonic stem cells in three-dimensional polymer scaffolds. Tissue Eng. Part A 16, 1115-1122.

Lockhart, D. J., Dong, H., Byrne, M. C. et al. (1996). Expression monitoring by hybridization to high-density oligonucleotide arrays. Nat. Biotechnol. 14, 1675-1680.

Logeart-Avramoglou, D., Oudina, K., Bourguignon, M. et al. (2010). In vitro and in vivo bioluminescent quantification of viable stem cells in engineered constructs. Tissue Eng. Part C Methods 16, 447-458.

Lu, B. (2009). Recent advances in using Drosophila to model neurodegenerative diseases. Apoptosis 14, 1008-1020.

Ludwig, T. E., Bergendahl, V., Levenstein, M. E. et al. (2006). Feeder-independent culture of human embryonic stem cells. Nat. Methods 3, 637-646.

Luker, G. D., Bardill, J. P., Prior, J. L. et al. (2002). Noninvasive bioluminescence imaging of herpes simplex virus type 1 infection and therapy in living mice. J. Virol. 76, 1214912161.

Luker, G. D. and Luker, K. E. (2008a). Optical imaging: current applications and future directions. J. Nucl. Med. 49, 1-4.

Luker, K. E. and Luker, G. D. (2008b). Applications of bioluminescence imaging to antiviral research and therapy: multiple luciferase enzymes and quantitation. Antiviral Res. 78, 179187.

Luker, K. E. and Luker, G. D. (2010). Bioluminescence imaging of reporter mice for studies of infection and inflammation. Antiviral Res. 86, 93-100.

MacDonald, J. S. and Robertson, R. T. (2009). Toxicity testing in the $21^{\text {st }}$ century: a view from the pharmaceutical industry. Toxicol. Sci. 110, 40-46.

Maggioli, J., Hoover, A. and Weng, L. (2006). Toxicogenomic analysis methods for predictive toxicology. J. Pharmacol. Toxicol. Methods 53, 31-37.

Malstrom, S. E., Jekic-McMullen, D., Sambucetti, L. et al. (2004). In vivo bioluminescent monitoring of chemical toxicity using heme oxygenase-luciferase transgenic mice. Toxicol. Appl. Pharmacol. 200, 219-228.
Mann, M. and Jensen, O. N. (2003). Proteomic analysis of posttranslational modifications. Nat. Biotechnol. 21, 255-261.

Mardis, E. R. (2008). Next-generation DNA sequencing methods. Annu. Rev. Genomics Hum. Genet. 9, 387-402.

Mathijs, K., Kienhuis, A. S., Brauers, K. J. et al. (2009). Assessing the metabolic competence of sandwich-cultured mouse primary hepatocytes. Drug Metab. Dispos. 37, 1305-1311.

Mayr, L. M. and Bojanic, D. (2009). Novel trends in highthroughput screening. Curr. Opin. Pharmacol. 9, 580-588.

Mazzoleni, G., Di Lorenzo, D. and Steimberg, N. (2009). Modelling tissues in 3D: the next future of pharmaco-toxicology and food research? Genes. Nutr. 4, 13-22.

McKusick, V. A. (1997). Genomics: structural and functional studies of genomes. Genomics 45, 244-249.

Meek, B. and Doull, J. (2009). Pragmatic challenges for the vision of toxicity testing in the $21^{\text {st }}$ century in a regulatory context: another Ames test? ... or a new edition of "the Red Book"? Toxicol. Sci. 108, 19-21.

Merkel, J. S., Michaud, G. A., Salcius, M. et al. (2005). Functional protein microarrays: just how functional are they? Curr. Opin. Biotechnol. 16, 447-452.

Miranda, J. P., Rodrigues, A., Tostoes, R. M. et al. (2010). Extending hepatocyte functionality for drug-testing applications using high-viscosity alginate-encapsulated three-dimensional cultures in bioreactors. Tissue Eng. Part C Methods 16, 12231232 .

Mishra, K. P., Ganju, L., Sairam, M. et al. (2008). A review of high throughput technology for the screening of natural products. Biomed. Pharmacother. 62, 94-98.

Monnet-Tschudi, F., Zurich, M. G. and Honegger, P. (1996). Comparison of the developmental effects of two mercury compounds on glial cells and neurons in aggregate cultures of rat telencephalon. Brain Res. 741, 52-59.

Monnet-Tschudi, F., Zurich, M. G. and Honegger, P. (2007). Neurotoxicant-induced inflammatory response in three-dimensional brain cell cultures. Hum. Exp. Toxicol. 26, 339-346.

Moon, Y. J., Lee, M. W., Yoon, H. H. et al. (2008). Hepatic differentiation of cord blood-derived multipotent progenitor cells (MPCs) in vitro. Cell Biol. Int. 32, 1293-1301.

Moors, M., Rockel, T. D., Abel, J. et al. (2009). Human neurospheres as three-dimensional cellular systems for developmental neurotoxicity testing. Environ. Health Perspect. 117, 1131-1138.

Morisseau, C., Merzlikin, O., Lin, A. et al. (2009). Toxicology in the fast lane: application of high-throughput bioassays to detect modulation of key enzymes and receptors. Environ. Health Perspect. 117, 1867-1872.

Morley, E. J., Hirsch, H. V., Hollocher, K. et al. (2003). Effects of chronic lead exposure on the neuromuscular junction in Drosophila larvae. Neurotoxicology 24, 35-41.

Morris, M. C. (2010). Fluorescent biosensors of intracellular targets from genetically encoded reporters to modular polypeptide probes. Cell Biochem. Biophys. 56, 19-37.

Mun, G. C., Aardema, M. J., Hu, T. et al. (2009). Further development of the EpiDerm 3D reconstructed human skin micronucleus (RSMN) assay. Mutat. Res. 673, 92-99. 
Navarro-Alvarez, N., Soto-Gutierrez, A., Yuasa, T. et al. (2008). Long-term culture of Japanese human embryonic stem cells in feeder-free conditions. Cell Transplant. 17, 27-33.

Netzlaff, F., Lehr, C. M., Wertz, P. W. et al. (2005). The human epidermis models EpiSkin, SkinEthic and EpiDerm: an evaluation of morphology and their suitability for testing phototoxicity, irritancy, corrosivity, and substance transport. Eur. J. Pharm. Biopharm. 60, 167-178.

Nichols, C. D. (2006). Drosophila melanogaster neurobiology, neuropharmacology, and how the fly can inform central nervous system drug discovery. Pharmacol. Ther. 112, 677-700.

Nicholson, J. K. and Lindon, J. C. (2008). Systems biology: Metabonomics. Nature 455, 1054-1056.

Niederlein, A., Meyenhofer, F., White, D. et al. (2009). Image analysis in high-content screening. Comb. Chem. High Throughput Screen. 12, 899-907.

Nishikawa, S., Jakt, L. M. and Era, T. (2007). Embryonic stemcell culture as a tool for developmental cell biology. Nat. Rev. Mol. Cell Biol. 8, 502-507.

NRC (2000). Scientific frontiers in developmental toxicology and risk assessment. Washington, DC: National Academy Press.

NRC (2007). Toxicity testing in the $21^{\text {st }}$ century: $a$ vision and $a$ strategy. Washington, DC: National Academy Press.

Ntziachristos, V., Bremer, C. and Weissleder, R. (2003). Fluorescence imaging with near-infrared light: new technological advances that enable in vivo molecular imaging. Eur. Radiol. 13, 195-208.

O'Brien, P. J., Irwin, W., Diaz, D. et al. (2006). High concordance of drug-induced human hepatotoxicity with in vitro cytotoxicity measured in a novel cell-based model using high content screening. Arch. Toxicol. 80, 580-604.

O'Malley, J., Woltjen, K. and Kaji, K. (2009). New strategies to generate induced pluripotent stem cells. Curr. Opin. Biotechnol. 20, 516-521.

O'Rourke, E. J., Conery, A. L. and Moy, T. I. (2009). Whole-animal high-throughput screens: the C. elegans model. Methods Mol. Biol. 486, 57-75.

Oba, Y., Ojika, M. and Inouye, S. (2003). Firefly luciferase is a bifunctional enzyme: ATP-dependent monooxygenase and a long chain fatty acyl-CoA synthetase. FEBS Lett. 540, 251-254.

Olson, H., Betton, G., Robinson, D. et al. (2000). Concordance of the toxicity of pharmaceuticals in humans and in animals. Regul. Toxicol. Pharmacol. 32, 56-67.

Omenn, G. S., Aebersold, R. and Paik, Y. K. (2009). $7^{\text {th }}$ HUPO World Congress of Proteomics: launching the second phase of the HUPOPlasma Proteome Project (PPP-2) 16-20 August 2008, Amsterdam, The Netherlands. Proteomics 9, 4-6.

Ortiz, J. G., Opoka, R., Kane, D. et al. (2009). Investigating arsenic susceptibility from a genetic perspective in Drosophila reveals a key role for glutathione synthetase. Toxicol. Sci. $107,416-426$.

Osman, A. M., van Dartel, D. A., Zwart, E. et al. (2010). Proteome profiling of mouse embryonic stem cells to define markers for cell differentiation and embryotoxicity. Reprod. Toxicol. 30, 322-332.
Pampaloni, F., Stelzer, E. H. and Masotti, A. (2009). Three-dimensional tissue models for drug discovery and toxicology. Recent Pat. Biotechnol. 3, 103-117.

Parng, C., Roy, N. M., Ton, C. et al. (2007). Neurotoxicity assessment using zebrafish. J. Pharmacol. Toxicol. Methods 55, 103-112.

Pauli, J., Vag, T., Haag, R. et al. (2009). An in vitro characterization study of new near infrared dyes for molecular imaging. Eur. J. Med. Chem. 44, 3496-3503.

Peterson, R. T., Nass, R., Boyd, W. A. et al. (2008). Use of nonmammalian alternative models for neurotoxicological study. Neurotoxicology 29, 546-555.

Pfaller, W. and Gstraunthaler, G. (1998). Nephrotoxicity testing in vitro - what we know and what we need to know. Environ. Health Perspect. 106, Suppl. 2, 559-569.

Phalen, R. F. (2010). Commentary on "Toxicity testing in the $21^{\text {st }}$ century: a vision and a strategy". Hum. Exp. Toxicol. 29, $11-14$.

Phizicky, E., Bastiaens, P. I., Zhu, H. et al. (2003). Protein analysis on a proteomic scale. Nature 422, 208-215.

Pittenger, M. F. (2008). Mesenchymal stem cells from adult bone marrow. Methods Mol. Biol. 449, 27-44.

Pourahmad, J., Hosseini, M. J., Eskandari, M. R. et al. (2010). Mitochondrial/lysosomal toxic cross-talk plays a key role in cisplatin nephrotoxicity. Xenobiotica 40, 763-771.

Purcell, W. M., Atterwill, C. K. and Xu, J. (2003). Cryopreservation of organotypic brain spheroid cultures. ATLA 31, 563573.

Radio, N. M., Breier, J. M., Shafer, T. J. et al. (2008). Assessment of chemical effects on neurite outgrowth in PC12 cells using high content screening. Toxicol. Sci. 105, 106-118.

Rambhatla, L., Chiu, C. P., Kundu, P. et al. (2003). Generation of hepatocyte-like cells from human embryonic stem cells. Cell Transplant. 12, 1-11.

Rand, M. D., Dao, J. C. and Clason, T. A. (2009). Methylmercury disruption of embryonic neural development in Drosophila. Neurotoxicology 30, 794-802.

Rand, M. D. (2010). Drosophotoxicology: the growing potential for Drosophila in neurotoxicology. Neurotoxicol. Teratol.32, 74-83.

Robertson, D. G. (2005). Metabonomics in toxicology: a review. Toxicol. Sci. 85, 809-822.

Ross, P. L., Huang, Y. N., Marchese, J. N. et al. (2004). Multiplexed protein quantitation in Saccharomyces cerevisiae using amine-reactive isobaric tagging reagents. Mol. Cell Proteomics 3, 1154-1169.

Rovida, C. and Hartung, T. (2009). Re-evaluation of animal numbers and costs for in vivo tests to accomplish REACH legislation requirements for chemicals - a report by the transatlantic think tank for toxicology $\left(\mathrm{t}^{4}\right)$. ALTEX 26, 187208.

Russom, C. L., Breton, R. L., Walker, J. D. et al. (2003). An overview of the use of quantitative structure-activity relationships for ranking and prioritizing large chemical inventories for environmental risk assessments. Environ. Toxicol. Chem. $22,1810-1821$. 
Sadikot, R. T. and Blackwell, T. S. (2005). Bioluminescence imaging. Proc. Am. Thorac. Soc. 2, 537-540, 511-532.

Sadikot, R. T. and Blackwell, T. S. (2008). Bioluminescence: imaging modality for in vitro and in vivo gene expression. Methods Mol. Biol. 477, 383-394.

Sanger, F., Nicklen, S. and Coulson, A. R. (1977). DNA sequencing with chain-terminating inhibitors. Proc. Natl. Acad. Sci. U S A 74, 5463-5467.

Schardein, J. L., Schwetz, B. A. and Kenel, M. F. (1985). Species sensitivities and prediction of teratogenic potential. Environ. Health Perspect. 61, 55-67.

Schena, M., Shalon, D., Davis, R. W. et al. (1995). Quantitative monitoring of gene expression patterns with a complementary DNA microarray. Science 270, 467-470.

Schettler, T. (2001). Toxic threats to neurologic development of children. Environ. Health Perspect. 109, Suppl. 6, 813-816.

Schmidt, C. W. (2009). TOX 21: new dimensions of toxicity testing. Environ. Health Perspect. 117, A348-353.

Schoonen, W. G., Westerink, W. M. and Horbach, G. J. (2009). High-throughput screening for analysis of in vitro toxicity. EXS 99, 401-452.

Schulz, T. C., Noggle, S. A., Palmarini, G. M. et al. (2004). Differentiation of human embryonic stem cells to dopaminergic neurons in serum-free suspension culture. Stem Cells 22, 1218-1238.

Schuster, S. C. (2008). Next-generation sequencing transforms today's biology. Nat. Methods 5, 16-18.

Schwartz, S. L. (2010). Commentary on "Toxicity testing in the $21^{\text {st }}$ century: a vision and a strategy". Hum. Exp. Toxicol. 29, 15-19.

Seidle, T. and Stephens, M. L. (2009). Bringing toxicology into the $21^{\text {st }}$ century: a global call to action. Toxicol. In Vitro 23, 1576-1579.

Smith, C. A., O’Maille, G., Want, E. J. et al. (2005). METLIN: a metabolite mass spectral database. Ther. Drug Monit. 27, 747-751.

Smits, A. M., van Vliet, P., Metz, C. H. et al. (2009). Human cardiomyocyte progenitor cells differentiate into functional mature cardiomyocytes: an in vitro model for studying human cardiac physiology and pathophysiology. Nat. Protoc. 4, 232-243.

Sokolowski, M. B. (2001). Drosophila: genetics meets behaviour. Nat. Rev. Genet. 2, 879-890.

Soto-Gutierrez, A., Navarro-Alvarez, N., Caballero-Corbalan, J. et al. (2008). Endoderm induction for hepatic and pancreatic differentiation of ES cells. Acta Med. Okayama 62, 63-68.

Spielmann, H., Seiler, A., Bremer, S. et al. (2006). The practical application of three validated in vitro embryotoxicity tests. The report and recommendations of an ECVAM/ZEBET workshop (ECVAM workshop 57). ATLA 34, 527-538.

Steel, D., Hyllner, J. and Sartipy, P. (2009). Cardiomyocytes derived from human embryonic stem cells - characteristics and utility for drug discovery. Curr. Opin. Drug Discov. Devel. $12,133-140$.

Stevens, J. L. (2006). Future of toxicology - mechanisms of toxicity and drug safety: where do we go from here? Chem. Res. Toxicol. 19, 1393-1401.
Stevens, M. M. (2009). Toxicology: Testing in the third dimension. Nat. Nanotechnol. 4, 342-343.

Stoevesandt, O., Taussig, M. J. and He, M. (2009). Protein microarrays: high-throughput tools for proteomics. Expert Rev. Proteomics 6, 145-157.

Strauss, V., Wiemer, J., Leibold, E. et al. (2009). Influence of strain and sex on the metabolic profile of rats in repeated dose toxicological studies. Toxicol. Lett. 191, 88-95.

Sullivan, G. J., Hay, D. C., Park, I. H. et al. (2010). Generation of functional human hepatic endoderm from human induced pluripotent stem cells. Hepatology 51, 329-335.

Sumner, S., Snyder, R., Burgess, J. et al. (2009). Metabolomics in the assessment of chemical-induced reproductive and developmental outcomes using non-invasive biological fluids: application to the study of butylbenzyl phthalate. J. Appl. Toxicol. 29, 703-714.

Suzuki, T., Matsuzaki, T., Hagiwara, H. et al. (2007). Recent advances in fluorescent labeling techniques for fluorescence microscopy. Acta Histochem. Cytochem. 40, 131-137.

Swedlow, J. R. and Platani, M. (2002). Live cell imaging using wide-field microscopy and deconvolution. Cell Struct. Funct. 27, 335-341.

Swistowski, A., Peng, J., Liu, Q. et al. (2010). Efficient generation of functional dopaminergic neurons from human induced pluripotent stem cells under defined conditions. Stem Cells 28, 1893-1904.

Takahashi, K. and Yamanaka, S. (2006). Induction of pluripotent stem cells from mouse embryonic and adult fibroblast cultures by defined factors. Cell 126, 663-676.

Tanaka, H. (2010). Omics-based medicine and systems pathology. A new perspective for personalized and predictive medicine. Methods Inf. Med. 49, 173-185.

Thomas, R. S., Rank, D. R., Penn, S. G. et al. (2002). Application of genomics to toxicology research. Environ. Health Perspect. 110, Suppl. 6, 919-923.

Thongboonkerd, V. (2008). Urinary proteomics: towards biomarker discovery, diagnostics and prognostics. Mol. Biosyst. 4, 810-815.

Tiffany-Castiglioni, E., Ehrich, M., Dees, L. et al. (1999). Bridging the gap between in vitro and in vivo models for neurotoxicology. Toxicol. Sci. 51, 178-183.

Tinois, E., Tiollier, J., Gaucherand, M. et al. (1991). In vitro and post-transplantation differentiation of human keratinocytes grown on the human type IV collagen film of a bilayered dermal substitute. Exp. Cell Res. 193, 310-319.

Toh, Y. C., Lim, T. C., Tai, D. et al. (2009). A microfluidic 3D hepatocyte chip for drug toxicity testing. Lab. Chip 9, 20262035.

Trujillo, E., Davis, C. and Milner, J. (2006). Nutrigenomics, proteomics, metabolomics, and the practice of dietetics. $J$. Am. Diet. Assoc. 106, 403-413.

Truman, J. W. and Bate, M. (1988). Spatial and temporal patterns of neurogenesis in the central nervous system of Drosophila melanogaster. Dev. Biol. 125, 145-157.

Truman, J. W. (1990). Metamorphosis of the central nervous system of Drosophila. J. Neurobiol. 21, 1072-1084. 
Tuschl, G., Hrach, J., Walter, Y. et al. (2009). Serum-free collagen sandwich cultures of adult rat hepatocytes maintain liver-like properties long term: a valuable model for in vitro toxicity and drug-drug interaction studies. Chem. Biol. Interact. 181, 124-137.

Ullmann, K., Wiencierz, A. M., Muller, C. et al. (2008). A highthroughput reporter gene assay to prove the ability of natural compounds to modulate glutathione peroxidase, superoxide dismutase and catalase gene promoters in V79 cells. Free Radic. Res. 42, 746-753.

Ullrich, A., Stolz, D. B., Ellis, E. C. et al. (2009). Long term cultures of primary human hepatocytes as an alternative to drug testing in animals. ALTEX 26, 295-302.

Uroukov, I. S., Ma, M., Bull, L. et al. (2006). Electrophysiological measurements in three-dimensional in vivo-mimetic organotypic cell cultures: preliminary studies with hen embryo brain spheroids. Neurosci. Lett. 404, 33-38.

Usami, M., Mitsunaga, K., Nakazawa, K. et al. (2008). Proteomic analysis of selenium embryotoxicity in cultured postimplantation rat embryos. Birth Defects Res. B Dev. Reprod. Toxicol. 83, 80-96.

US EPA (1998a). Health effects guidelines OPPTS 870.6300 developmental neurotoxicity study. http://www.epa.gov/ocspp/pubs/frs/publications/Test_Guidelines/series870.htm

US EPA (1998b). Chemical hazard data availability study. What do we really know about the safety of high production volume chemicals? http://www.epa.gov/chemrtk/pubs/general/ hazchem.pdf

Vallier, L., Touboul, T., Brown, S. et al. (2009). Signaling pathways controlling pluripotency and early cell fate decisions of human induced pluripotent stem cells. Stem Cells 27, 26552666.

van Dartel, D. A., Pennings, J. L., van Schooten, F. J. et al. (2010b). Transcriptomics-based identification of developmental toxicants through their interference with cardiomyocyte differentiation of embryonic stem cells. Toxicol. Appl. Pharmacol. 243, 420-428.

van Dartel, D. A., Pennings, J. L., de la Fonteyne, L. J. et al. (2010a). Monitoring developmental toxicity in the embryonic stem cell test using differential gene expression of differentiation-related genes. Toxicol. Sci. 116, 130-139.

van Delft, J. H., van Agen, E., van Breda, S. G. et al. (2005). Comparison of supervised clustering methods to discriminate genotoxic from non-genotoxic carcinogens by gene expression profiling. Mutat. Res. 575, 17-33.

van Hoof, D., Heck, A. J., Krijgsveld, J. et al. (2008). Proteomics and human embryonic stem cells. Stem Cell Res. 1, 169182.

van Ravenzwaay, B., Cunha, G. C., Leibold, E. et al. (2007). The use of metabolomics for the discovery of new biomarkers of effect. Toxicol. Lett. 172, 21-28.

van Vliet, E., Morath, S., Eskes, C. et al. (2008). A novel in vitro metabolomics approach for neurotoxicity testing, proof of principle for methyl mercury chloride and caffeine. Neurotoxicology 29, 1-12.

van Vliet, E., Stoppini, L., Balestrino, M. et al. (2007). Electro- physiological recording of re-aggregating brain cell cultures on multi-electrode arrays to detect acute neurotoxic effects. Neurotoxicology 28, 1136-1146.

VanMeter, A., Signore, M., Pierobon, M. et al. (2007). Reversephase protein microarrays: application to biomarker discovery and translational medicine. Expert Rev. Mol. Diagn. 7, 625-633.

Vendrell, I., Carrascal, M., Campos, F. et al. (2010). Methylmercury disrupts the balance between phosphorylated and nonphosphorylated cofilin in primary cultures of mice cerebellar granule cells. A proteomic study. Toxicol. Appl. Pharmacol. 242, 109-118.

Vereyken, E. J., Fluitsma, D. M., Bolijn, M. J. et al. (2009). An in vitro model for de- and remyelination using lysophosphatidyl choline in rodent whole brain spheroid cultures. Glia 57, 1326-1340.

Waddell, W. J. (2010). Commentary on "Toxicity testing in the $21^{\text {st }}$ century: a vision and a strategy". Hum. Exp. Toxicol. 29, 31-32.

Walgren, R. A. and McLeod, H. L. (2005). Small inhibitory RNA - a tool for credentialing candidate genes. Pharmacogenomics 6, 281-292.

Walker, T. M., Davenport-Jones, J. E., Fox, R. M. et al. (1999). The neurotoxic effects of methylenedioxymethamphetamine (MDMA) and its metabolites on rat brain spheroids in culture. Cell Biol. Toxicol. 15, 137-142.

Walker, N. J. (2001). Real-time and quantitative PCR: applications to mechanism-based toxicology. J. Biochem. Mol. Toxicol. 15, 121-127.

Walker, J. D. and Carlsen, L. (2002). QSARs for identifying and prioritizing substances with persistence and bioconcentration potential. SAR QSAR Environ. Res. 13, 713-725.

Wang, S., Nagrath, D., Chen, P. C. et al. (2008). Three-dimensional primary hepatocyte culture in synthetic self-assembling peptide hydrogel. Tissue Eng. Part A 14, 227-236.

Waters, M. D. and Fostel, J. M. (2004). Toxicogenomics and systems toxicology: aims and prospects. Nat. Rev. Genet. 5, 936-948.

Waters, M. D., Jackson, M. and Lea, I. (2010). Characterizing and predicting carcinogenicity and mode of action using conventional and toxicogenomics methods. Mutat. Res. 705, 184200.

Wegner, B., Baer, P., Gauer, S. et al. (2005). Caspofungin is less nephrotoxic than amphotericin B in vitro and predominantly damages distal renal tubular cells. Nephrol. Dial. Transplant. 20, 2071-2079.

Wen, J., Xia, Q., Lu, C. et al. (2007). Proteomic analysis of cardiomyocytes differentiation in mouse embryonic carcinoma P19CL6 cells. J. Cell Biochem. 102, 149-160.

West, P. R., Weir, A. M., Smith, A. M. et al. (2010). Predicting human developmental toxicity of pharmaceuticals using human embryonic stem cells and metabolomics. Toxicol. Appl. Pharmacol. 247, 18-27.

Wetmore, B. A. and Merrick, B. A. (2004). Toxicoproteomics: proteomics applied to toxicology and pathology. Toxicol. Pathol. 32, 619-642. 
Williams, P. L., Anderson, G. L., Johnstone, J. L. et al. (2000). Caenorhabditis elegans as an alternative animal species. $J$. Toxicol. Environ. Health A 61, 641-647.

Wilson, K., Yu, J., Lee, A. et al. (2008). In vitro and in vivo bioluminescence reporter gene imaging of human embryonic stem cells. J. Vis Exp. 14, pii 740.

Wishart, D. S. (2007). Human Metabolome Database: completing the 'human parts list'. Pharmacogenomics 8, 683-686.

Xing, X., Du, M., Zhang, Y. et al. (2009). Adverse effects of metal exposure on chemotaxis towards water-soluble attractants regulated mainly by ASE sensory neuron in nematode Caenorhabditis elegans. J. Environ. Sci. (China) 21, 1684-1694.

Yamashita, A., Nishikawa, S. and Rancourt, D. E. (2010). Identification of five developmental processes during chondrogenic differentiation of embryonic stem cells. PLoS One 5, e10998.

Yan, Y., Yang, D., Zarnowska, E. D. et al. (2005). Directed differentiation of dopaminergic neuronal subtypes from human embryonic stem cells. Stem Cells 23, 781-790.

Yang, L., Ho, N. Y., Alshut, R. et al. (2009). Zebrafish embryos as models for embryotoxic and teratological effects of chemicals. Reprod. Toxicol. 28, 245-253.

Yoshitomi, S., Ikemoto, K., Takahashi, J. et al. (2001). Establishment of the transformants expressing human cytochrome P450 subtypes in HepG2, and their applications on drug metabolism and toxicology. Toxicol. In Vitro 15, 245-256.

Yu, J., Vodyanik, M. A., Smuga-Otto, K. et al. (2007). Induced pluripotent stem cell lines derived from human somatic cells. Science 318, 1917-1920.

Zanella, F., Lorens, J. B. and Link, W. (2010). High content screening: seeing is believing. Trends Biotechnol. 28, 237245.
Zbinden, G. (1990a). In vitro methods, past successes and future challenges. Acta Physiol. Scand., Suppl. 592, 9-12.

Zbinden, G. (1990b). [Alternative methods, the present and future]. Therapie 45, 347-350.

Zhang, J., Wilson, G. F., Soerens, A. G. et al. (2009). Functional cardiomyocytes derived from human induced pluripotent stem cells. Circ. Res. 104, e30-41.

Zidek, N., Hellmann, J., Kramer, P. J. et al. (2007). Acute hepatotoxicity: a predictive model based on focused illumina microarrays. Toxicol. Sci. 99, 289-302.

Zock, J. M. (2009). Applications of high content screening in life science research. Comb. Chem. High Throughput Screen $12,870-876$.

Zurich, M. G., Honegger, P., Schilter, B. et al. (2004). Involvement of glial cells in the neurotoxicity of parathion and chlorpyrifos. Toxicol.Appl. Pharmacol. 201,97-104

\section{Acknowledgement}

I would like to acknowledge Dr. Thomas Hartung and Dr. Alan Goldberg for their help in preparing the manuscript.

\section{Correspondence to}

Erwin van Vliet, PhD

Johns Hopkins Bloomberg School of Public Health

Dept. Environmental Health Sciences

Center for Alternatives to Animal Testing

615 N. Wolfe St.

Baltimore, MD, 21205, USA

e-mail: evanvlie@jhsph.edu 